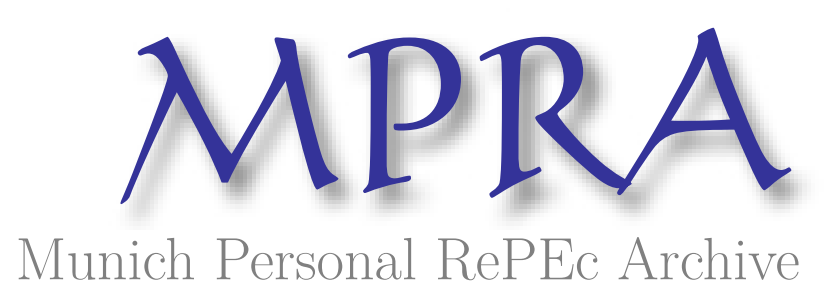

\title{
Economics of Voluntary Information Sharing
}

Liberti, Jose and Sturgess, Jason and Sutherland, Andrew

DePaul University; Northwestern University, Queen Mary University of London, MIT

2018

Online at https://mpra.ub.uni-muenchen.de/93673/

MPRA Paper No. 93673, posted 04 May 2019 22:27 UTC 


\title{
Economics of Voluntary Information Sharing*
}

\author{
José Liberti, Jason Sturgess, and Andrew Sutherland ${ }^{+}$
}

August 2018

\begin{abstract}
We show that lenders join a U.S. commercial credit bureau when information asymmetries between incumbents and entrants create an adverse selection problem that hinders market entry. Lenders also delay joining when information asymmetries protect them from competition in existing markets, consistent with lenders trading off new market entry against heightened competition. We exploit shocks to information coverage to show that lenders enter new markets after joining the bureau in a pattern consistent with this trade-off. Our results illuminate why intermediaries voluntarily share information and show how financial technology that mitigates information asymmetries can shape the boundaries of lending.
\end{abstract}

Keywords: information sharing, adverse selection, specialization, financial intermediation, collateral, credit bureaus, fintech.

JEL Codes: G21, G32

\footnotetext{
* We appreciate helpful comments from Phil Berger, Philip Bond, Mike Burkhart, John Core, Hans Degryse, Doug Diamond, Daniel Ferreria, Juanita Gonzalez-Uribe, Daniel Green, Rajkamal Iyer, Christian Leuz, Xiumin Martin, David Matsa, Will Mullins, Marco Pagano, Richard Rosen, Antoinette Schoar, Enrique Schroth, Amit Seru, Chester Spatt, Per Stromberg, Javier Suarez, Rodrigo Verdi; discussants Martin Brown, Jian Cai, Giovanni Dell'Ariccia, Vasso Ioannidou, Anna Kovner, Elena Loutskina, Raoul Minetti, Abhiroop Mukherjee, Jordan Nickerson, Clemens Otto, Daniel Paravisini, Anthony Saunders, and Moqi Xu; and participants at the Chicago Financial Institutions Conference, China International Conference in Finance, Edinburgh Corporate Finance Conference, European Banking Center Network Conference (Lancaster), European Finance Association meetings, European Summer Symposium in Financial Markets (ESSFM), FDIC Center for Financial Research Annual Bank Research Conference, Federal Reserve Bank of Chicago, London Business School, MIT, Midwest Finance Association Annual Meetings, Northwestern University Kellogg School of Management, Review of Corporate Finance Studies Conference, University of Rochester, Washington University in St. Louis, and Western Finance Association. We are grateful to PayNet for providing data. Financial support was provided by DePaul University and Northwestern University (Liberti), DePaul University and Queen Mary University of London (Sturgess), and MIT (Sutherland). Any errors or omissions are our own. This paper was previously circulated under the title "Information Sharing and Lender Specialization: Evidence from the U.S. Commercial Lending Market."

+ Liberti: DePaul University and Northwestern University, jliberti@ depaul.edu; Sturgess: Queen Mary University of London, j.sturgess@qmul.ac.uk; Sutherland: MIT, ags1@mit.edu.
} 


\section{Introduction}

Advances in technology have changed the way financial intermediaries use and share information. In most modern credit markets, lenders exchange contract terms and delinquency records through sharing arrangements (Djankov, McLiesh, and Shleifer 2007). Many of these arrangements operate voluntarily through private credit bureaus in the largest credit markets. Private bureaus provide near universal coverage of individuals in the United States, United Kingdom, Japan, Germany, and Canada, while mandated credit registries are negligible in these markets (World Bank 2016).

Sharing information reduces information asymmetries between borrowers and lenders, which aids screening and monitoring, improves the match between lenders and borrowers, and enhances access to credit for creditworthy borrowers (Padilla and Pagano 1997). However, because these same features increase competition for borrowers, lenders may prefer not to share information (Pagano and Jappelli 1993). In this paper, we study when lenders decide to voluntarily share information and how their expansion is aided by shared information.

Because few settings allow researchers to observe the decision to share information or lender behavior before and after sharing, the motives and consequences of this sharing are not well understood. Our study uses data from the PayNet credit bureau, which includes the equipment finance contracts of 207 lenders joining in a staggered pattern between 2001 and 2014. PayNet filled a gap in the U.S. commercial credit market, where, unlike in consumer credit, lenders had no access to historical loan performance data from other lenders. A novel feature of the PayNet data is that members must share both ongoing and past contracts, allowing us to track lenders' exposures before and after sharing.

We show that, although the threat of competition deters information sharing, lenders have incentives to share when doing so can reduce adverse selection problems that inhibit entry to competitive credit markets. Lenders that enter the bureau earlier face greater adverse 
selection and entry barriers ex-ante in the potential (or equivalently, "new") markets into which they can expand. Early entrants also have fewer informational rents to lose by sharing because adverse selection is lower ex ante in their existing (equivalently, "home") markets. In tests examining the expansion dynamics of members, we confirm that lenders rely on bureau information to expand in new markets with higher adverse selection.

Our evidence on the sharing decision can be understood through the lens of Pagano and Jappelli (1993). They argue that lenders should be more likely to share information when the benefits of sharing - a reduction in information asymmetry - are high or the costs - the threat of increased competition - are low. We frame our results on how information asymmetries between lenders in new and existing markets affect when lenders join the bureau by building on Dell'Ariccia, Friedman, and Marquez (1999), Dell'Ariccia (2001), and Marquez (2002). They explore how information asymmetries between informed incumbents and uninformed entrants affect the structure of credit markets and highlight that information sharing can mitigate the adverse selection problems associated with expansion. Intuitively, our results show that lenders delay sharing to protect existing markets where they can extract informational rents and share earlier when they seek to enter markets where adverse selection is high.

Our first set of tests investigates the market, lender, and bureau characteristics that influence lenders' decisions to join PayNet. For market characteristics, we estimate lender concentration, credit growth, and delinquency rates in each market to capture the adverse selection facing entrants, due to incumbents' proprietary information on borrowers, which gives them an information advantage when competing for borrowers. Entrants face greater adverse selection when proprietary information is concentrated among fewer incumbents and when incumbents have more proprietary information on the loan application pool, either because new credit demand is low or past delinquencies are high (Dell'Ariccia et al. 1999; Dell'Ariccia 2001; Marquez 2002). 
We define a credit market as the intersection of one of 23 collateral types and one of nine U.S. census regions. Thus, a lender's potential collateral-region markets are the collateral type $\mathrm{x}$ U.S. region pairs where the lender does not have exposure prior to sharing. We focus on collateral types because equipment finance lenders often specialize by type, rather than by industry, given the similarities in contract terms, default probabilities, resale markets, and enforcement mechanisms within an asset class (Carey et al. 1998; Benmelech et al. 2005; Eisfeldt and Rampini 2009; Murfin and Pratt 2017). ${ }^{1}$

We show that early PayNet participants face lower concentration in existing markets, and higher concentration, higher delinquency, and lower growth rates in potential markets. As the bureau grows, we find that those lenders with initial higher home market concentration and lower potential market concentration enter. We then examine how lender characteristics affect the entry decision. Those employing lending technology that relies less on private information, such as lenders that are larger or more diversified (Loutskina and Strahan 2011; Berger et al. 2017), enter sooner. ${ }^{2}$ Specialized lenders, possessing specific expertise in evaluating credit risks and collecting proprietary information, enter the bureau later. Last, we study bureau characteristics and show that the decision to enter is positively correlated with the breadth of membership in the lender's existing markets, consistent with bureau reputation and lenders' strategic actions influencing the entry decision.

Our second set of tests use detailed contract-level data to examine whether lenders expand after bureau entry in a pattern consistent with the motives for information sharing. We start by examining whether lenders expand into new geographic markets within the collateral types they specialize prior to joining the bureau. To separate the effect of information sharing

\footnotetext{
${ }^{1}$ For example, captives such as Caterpillar, John Deere, IBM, and Volvo are among the 10 largest lenders in the equipment finance market, while others lend against computers, copiers, forklifts, or trucks to an array of industries (Monitor 2015).

2 Throughout we use "lending technology" to describe the combination of screening and monitoring practices, reliance on private and public information, and organizational hierarchy that shape how a lender makes credit decisions (Stein 2002; Berger et al. 2005; Liberti and Mian 2009; Loutskina and Strahan 2011).
} 
on lending from the endogenous decision to join, our empirical design exploits the staggered entry of lenders and employs within lender-quarter estimation to identify how members' exposures respond to market-level shocks in information coverage stemming from new member entry. Of course, these shocks in coverage may be correlated with demand shocks. The second piece of our identification strategy is to compare lending patterns of incumbent lenders with those of nonmembers around the entry of new lenders through the inclusion of collateral type-region-quarter fixed effects. Hence, we can examine how a member's exposure in a particular collateral type-region-quarter responds to an information shock, due to the new entrant, while absorbing the contemporaneous change in exposure in the same collateral typeregion for the counterfactual nonmember.

Our identification strategy is perhaps best illustrated with an example. Consider the exposures of the following lenders, $\mathrm{A}$ and $\mathrm{B}$, which both finance agricultural equipment. Lender A joins the bureau in 2004, and Lender B joins in 2008. Now consider a third lender, $\mathrm{C}$, specializing in agricultural equipment, which enters in 2006. We predict a larger change in agricultural equipment exposure in 2007 for Lender A, which observes the new information from Lender $\mathrm{C}$ in the bureau, than Lender $\mathrm{B}$, which is not yet a member. To the extent that the agricultural equipment lending divisions of Lenders A and B are exposed to similar economic shocks, the differential increase in agricultural equipment lending around Lender $\mathrm{C}$ joining the bureau can be attributed to information sharing. We also observe a natural placebo in our setting: Lender A's exposures in non-agricultural collateral types (e.g., copiers) should not respond to information coverage shocks originating from Lender $\mathrm{C}$ joining.

We find that members increase their exposures in a collateral type-region in response to new lenders sharing information in the bureau but only when the coverage shock is relevant to that collateral type-region. A one standard deviation increase in the number of bureau contracts for a typical collateral type-region increases a member's credit exposure to that same 
collateral type-region by $7.4 \%$. By comparison, we detect no change in nonmembers' exposures, and, in placebo tests, we show that members' exposures to a given collateral typeregion do not respond to shocks to coverage in other collateral type-regions. Together, these results indicate that expansion is being driven by the availability of information in the bureau, rather than by unobservable lender business-model changes or conditions in collateral markets.

To reinforce our earlier findings on the sharing decision, we show that the relation between a lender's expansion and information coverage is stronger in new markets, especially those with high concentration where entrants face greater information barriers ex-ante. The results illustrate that information sharing allows lenders to expand in markets consistent with adverse selection hindering market entry.

Next, we examine whether members expand into related collateral types post information sharing. Lenders can protect themselves from heightened competition by focusing on core markets and developing expertise (Boot and Thakor 2000; Hauswald and Marquez 2006). Since collateral expertise is instrumental to screening and monitoring in our setting, we expect lenders to enter new collateral markets that share screening and monitoring technologies with their existing ones. We construct an index measuring the degree of relatedness between each pair of collateral types by identifying the pairs most commonly found together in lenders' portfolios. ${ }^{3}$ Intuitively, the index captures how similar two collateral types are in terms of screening and monitoring technologies. For example, it shows that telecommunications equipment relates highly to computer and copy equipment but not to railroad and logging equipment. We find that lenders, on average, enter new collateral markets that most closely resemble their existing collateral exposures. Information sharing strengthens this effect, suggesting that sharing accelerates entry into related collateral markets.

\footnotetext{
${ }^{3}$ The literature employs similar techniques to study how across-firm linkages explain productivity (Conley and Dupor 2003), the propagation of microeconomic shocks (di Giovanni et al. 2014), and diversification (Teece et al. 1994; Bryce and Winter 2009; Boehm et al. 2016).
} 
To build on our results showing that small and specialized lenders join the bureau later, we also examine whether lenders' expansion patterns vary by their lending technologies. We show that small and specialized lenders expand credit more than large and diversified ones, respectively, but that larger lenders increase contracting with small firms after joining.

The results highlight important differences in the way lending technology interacts with information sharing. Small and specialized lenders typically invest in private information, employ monitoring technologies specific to a given collateral type, and possess competitive advantages in markets where borrower information is predominantly soft, such as for small firms (Stein 2002; Chen et al. 2017; Liberti and Petersen 2017). However, this technology may not transfer across markets, and therefore small and specialized lenders may face barriers to entry in the absence of information sharing. Large lenders, in contrast, which rely more on hard information, face significant barriers to contracting with smaller borrowers. PayNet provides access to information on small borrowers from small lenders, which reduces the need to collect private information and enables larger lenders to expand credit to these borrowers.

One implication of our results is that borrowers should have easier access to specialized lenders, which should improve their access to credit. Consistent with this, we show that, after a borrower first has a credit file in the bureau, this borrower increases its number of relationships by $6.0 \%$ and credit by $11.8 \%$. We then show that access to specialized lenders enhances financial flexibility. Borrowers are more likely to start "off-cycle" relationships, as opposed to starting new relationships only upon the conclusion of old contracts. These results also suggest that lenders do not collude in protecting their own relationships.

To our knowledge, our study provides the first direct evidence on why lenders voluntarily share information. There is a lack of evidence on voluntary information sharing, despite continued growth in sharing among financial intermediaries in most markets. Prior work has focused on how competition shapes incentives to share information but has been 
limited to studying cross-country aggregate correlations between information sharing and competition (Bruhn, Fazari, and Kanz 2013) or providing evidence from an experimental credit market (Brown and Zehnder 2010).

We also contribute to the literature exploring the scope of lenders' exposures, by showing how technological improvements that reduce information asymmetries can shape the boundaries of lending. ${ }^{4}$ Our evidence is consistent with specialization fostering a comparative advantage in screening and monitoring (Winton, 1999), which lenders leverage to access new credit markets when adverse selection is reduced through information sharing, in contrast to the traditional model of delegated monitoring in which banks diversify (Diamond 1984; Boyd and Prescott 1986).

\section{Theoretical Background}

We study when lenders choose to join a credit bureau to share information, and how doing so aids their expansion. We argue that information asymmetry affects the structure of credit markets, by creating an adverse selection problem that acts as an entry barrier to new lenders. Sharing information can reduce this adverse selection problem. Theoretical research allows us to formulate hypotheses on the timing of lenders' decisions to share information and bureau members' lending dynamics.

Asymmetric information is a defining characteristic of credit markets. Lenders face uncertainty about a borrower's creditworthiness because they cannot observe some of the borrower's characteristics and actions. Over time, lenders alleviate these informational problems by collecting proprietary information. Borrowers then can become informationally captured by their lenders, limiting the degree to which new lenders can compete for their

\footnotetext{
${ }^{4}$ Economists have long studied the boundaries of the firm, but there is abundantly more evidence from industrial than credit markets (e.g., Berger and Ofek 1995; Rajan et al. 2000; Campa and Kedia 2002), despite considerable regulatory scrutiny of lenders' portfolio concentrations (Basel 2000; OCC 2011).
} 
business. Sharpe (1990) and Rajan (1992) show that, in such a market, lenders have incentives to build market share in anticipation of future informational rents.

Dell'Ariccia et al. (1999), Dell'Ariccia (2001), and Marquez (2002) explore how information asymmetry between informed incumbents and uninformed entrants affects the structure of credit markets. Their key insight is that information asymmetries can inhibit lender entry, not simply because borrower types are unknown but also because incumbents' proprietary information gives them an advantage: they have knowledge of previously rejected borrowers. This helps them determine whether credit applicants are new borrowers, unknown to all lenders, or bad borrowers that have been rejected by incumbents. Potential entrants, therefore, suffer an adverse selection problem, due to their inability to distinguish between the new borrowers and the previously rejected ones. This adverse selection is greater in markets where proprietary information is concentrated among fewer incumbents, because each incumbent has a higher probability of identifying bad borrowers. It is also greater when entrants lack specific expertise in evaluating credit risks and when the ratio of new to bad borrowers is low, either because there is low borrower turnover or a greater prevalence of bad borrowers.

Marquez (2002) examines how information asymmetry affects competition for borrowers among incumbents that each have proprietary information on a different subset of borrowers. In markets where there are many incumbents and proprietary information is dispersed, each incumbent is less likely to have an information advantage. In contrast, markets with proprietary information concentrated among fewer incumbents should exhibit more severe adverse selection problems, less competition between incumbents, and more opportunities to collect informational rents. Thus, lenders should have weaker incentives to share information when proprietary information is concentrated among fewer competitors in their home markets.

Pagano and Jappelli (1993) show that lenders' incentives to share information in a formal mechanism are greater when adverse selection problems are worse. In particular, they 
focus on when lenders collectively choose to share with each other. Despite the differences between their theory and our setting, where lenders individually choose to share information, the key insights from their theory help us understand the trade-offs that influence when lenders share information.

Although information sharing helps lenders overcome the adverse selection problem associated with new market entry, information sharing can intensify competition, and therefore lenders may not necessarily agree to share (Vives, 1990; and Padilla and Pagano, 1997). Therefore, lenders face a trade-off: they may participate, despite the loss of potential rents, if doing so sufficiently reduces adverse selection problems and if borrowers increase their efforts to avoid defaulting and being labeled bad credit risks (Padilla and Pagano 2000).

It follows that lenders should choose to share information sooner when information asymmetry problems are smaller in their home markets, where protection from competition from both incumbents and entrants is lower ex-ante, and when information asymmetry problems are larger in potential markets, where the barriers to entry are highest ex-ante. We thus expect that bureau entry will happen earlier for lenders in dispersed home markets and earlier for potential entrants facing new markets with concentrated lender bases. In addition, it follows that lenders should join sooner when there are higher levels of delinquencies in potential markets because a higher prevalence of bad types increases adverse selection problems.

A potential objection to this descriptive theory of entry timing is that, although members join to overcome entry barriers in concentrated markets, the lenders in these markets have little incentive to share information. However, as long as a lender is not competing solely in concentrated markets, then the trade-off between gaining access to new markets and protecting informational rents in existing markets matters for entry timing. In addition, even if a lender has little incentive to share information, the bureau affects the status quo such that the 
lender may not be able to protect her rents in a concentrated market if she does not join the bureau when other lenders do.

Once lenders join, the same adverse selection problems should influence lending patterns. First, we expect new lending to be focused in new markets, especially those with proprietary information concentrated among fewer lenders, where adverse selection problems are greatest ex-ante.

Second, as information sharing becomes more pervasive, competition for borrowers will increase (Vives 1990; Padilla and Pagano 1997). One way that lenders can protect themselves is to invest in expertise that differentiates them from rivals (Boot and Thakor 2000). Hauswald and Marquez (2006) show that, as entry costs decline and more lenders enter a market, lenders invest less in transferable expertise, more in sector-specific expertise, and focus on core markets. This focus on core markets helps lenders develop a comparative advantage in screening and monitoring (Winton 1999; Acharya et al. 2006; Paravisini et al. 2015) and earn rents (Sharpe 1990; Rajan 1992). In our secured commercial credit setting, collateral is an important dimension of expertise. Therefore we expect lenders to leverage their collateral expertise when entering new collateral markets by targeting collateral types that share screening and monitoring technologies with the lender's existing collateral exposures.

\section{Institutional Setting}

\subsection{The PayNet Credit Bureau}

The PayNet equipment finance bureau launched in $2001 .^{5}$ Since then, over 200 lenders have joined, including eight of the 10 largest lenders in the segment as well as a number of

\footnotetext{
${ }^{5}$ Sutherland (2018) uses the launch of PayNet to show information sharing reduces switching costs for small borrowers and compels lenders to be more transactional in their interactions with borrowers. Doblas-Madrid and Minetti (2013) use an earlier version of the PayNet database to investigate the impact of lender information sharing on firms' payment performance. Their results reveal that information sharing reduces contract delinquencies and defaults, particularly for informationally opaque firms.
} 
smaller captives and regional banks. As of August 2018, the PayNet database contained over \$1.6 trillion of obligations from 24 million contracts.

PayNet was founded to fill a gap in the U.S. small business lending market: while delinquency and contract information has been voluntarily shared among consumer lenders for decades, until 2001 commercial lenders in the U.S. equipment finance market regularly originated loans without knowing how the borrower had previously serviced similar liabilities (Ware 2002). Repositories such as Dun \& Bradstreet and Experian had limited coverage of the market and therefore lacked timely, detailed information about firms' outstanding liabilities or the length and quality of their payment history.

PayNet credit reports offer three innovations over competitors' products and the Uniform Commercial Code (UCC) public collateral filings. First, reports contain a detailed payment history of the borrower, including historical credit payments and delinquency status. Second, PayNet provides contract-level detail of all equipment term loans and leases. This was an important feature because, before PayNet, lenders could only observe payment records for much smaller non-loan obligations (e.g., utility bills) for most borrowers (Ware 2002). Third, members can query, for a fee, PayNet's credit file, proprietary credit score, and probability of default for each borrower. ${ }^{6}$

Like other voluntary credit bureaus, PayNet operates on the principle of reciprocity. Lenders may participate only if they agree to share all past, present, and future credit files with other members. PayNet does not sell or otherwise make bureau information available to nonmembers. As members of the bureau, lenders must purchase individual credit files for applicants or existing clients. PayNet's interface does not allow them to perform bulk

\footnotetext{
${ }^{6}$ Proprietary credit scores and default probabilities are estimated using all ongoing and past contract information for each borrower across all contracts in the bureau.
} 
downloads of credit files or data mine (e.g., by industry, location, or collateral type). ${ }^{7}$ Lender identities are anonymous in the bureau. ${ }^{8}$

Several features of PayNet and the U.S. equipment finance market serve to ensure the accuracy of shared information. First, to become members, lenders must invest significantly in technology to allow PayNet to pull information directly from their internal systems. Second, lenders are subject to PayNet's initial testing and ongoing audits to verify that shared information is complete and accurate. Additionally, PayNet cross-checks data against several sources, including the information shared by other lenders with similar exposures, the lender's prior information, trade and macroeconomic data, and public filings including UCC public collateral filings. ${ }^{9}$ Finally, PayNet punishes misreporting with exclusion from the bureau. Misreporting also exposes lenders to litigation from borrowers and other bureau members. ${ }^{10}$

\subsection{Sample and Descriptive Statistics}

We construct our dataset from a panel of 20,000 randomly chosen borrowers' credit files, detailing payment histories and terms for over 400,000 contracts between 1998 and 2014 . For each sample firm, we observe every contract with lenders that have joined PayNet, including those beginning and maturing before the lender joins. ${ }^{11}$ For each contract, we observe the amount, collateral type, maturity, payment frequency, guarantor requirement, and payment history as well as the state, industry, and age of the firm. ${ }^{12}$

PayNet classifies contracts as one of 23 collateral types. Agricultural equipment, construction equipment, computers, copiers and fax machines, and trucks are the most

\footnotetext{
${ }^{7}$ For similar reasons, lenders cannot join, download all credit files, and then quit.

${ }^{8}$ The appendix of Sutherland (2018) contains additional detail about PayNet and the equipment finance market.

${ }^{9}$ In the United States, lenders make UCC financing statement filings to establish their legal right to collateral if a borrower defaults. Because these filings are public and Secretaries of State maintain searchable online records dating back to the 1990s or earlier, PayNet can verify that a lender has shared a given contract.

${ }^{10}$ Together, these features help prevent lender manipulation of shared information to protect informational rents, as documented in a mandatory information sharing setting by Giannetti et al. (2017).

${ }^{11}$ Naturally, we cannot observe the contracts of lenders that never share information with PayNet. Note, however, that they comprise a limited share of the market, given the high degree of market concentration and PayNet's inclusion of eight of the 10 largest lenders as members.

${ }^{12}$ We cannot observe the interest rate charged for contracts and therefore cannot construct profitability measures.
} 
commonly observed collateral types in our sample. Collateral types vary in terms of the number of lenders with exposure. For example, Table A1 of the online appendix shows that approximately half of our sample lenders contract in computers; by comparison, only nine offer contracts for boats.

Table 1 summarizes the contract features and exposures for lenders in the quarter before they join PayNet. The typical contract size for the average (median) lender is $\$ 190,692$ $(\$ 76,308)$. Next, we measure each lender's exposure in terms of their number of outstanding contracts, collateral types, and collateral type-regions. The average (median) lender has 481.9 (32.0) contracts with the borrowers in our sample. Of the 23 collateral type categories in PayNet, the average (median) lender is involved in 5.2 (3.0) before joining. Our tests aggregate states into one of nine census regions. ${ }^{13}$ Collateral offerings typically span multiple regions, as the average (median) lender has 18.7 (8.0) collateral type-region exposures. Seventy-five percent of the typical lender's contracts are leases.

\section{Voluntary Information Sharing and Credit Bureau Entry}

In this section, we use our theoretical framework to model how the costs and benefits of information sharing influence the timing of lender bureau entry. To capture these costs and benefits, we measure the concentration of credit in the markets the lender competes in (Home Market $H H I$ ) and the markets where the lender has no exposure (New Market HHI). We measure each lender's market concentration as follows. First, we measure the market concentration in each collateral type-region as the credit-weighted HHI that quarter. ${ }^{14}$ Second, we estimate a lender's home market concentration as the equal-weighted collateral type-region

\footnotetext{
${ }^{13}$ The regions include the Northeast, Middle Atlantic, East North Central, West North Central, South Atlantic, East South Central, West South Central, Mountain, and Pacific Divisions. See http://www2.census.gov/geo/docs/maps-data/maps/reg_div.txt for state-to-region mappings.

${ }^{14}$ That is, we sum the squared market shares for lenders in the collateral type-region that quarter, where market shares are based on total credit for the collateral type-region.
} 
HHI, based on the collateral type-regions the lender has exposure to when it first appears in the data, that is, before entering the bureau. Third, we estimate a lender's new market concentration as the equal-weighted collateral type-region HHI, based on the collateral type-regions the lender does not have exposure to when it first appears in the data. ${ }^{15}$

Table 1 presents descriptive statistics on market concentration. The average home (new) market HHI measured at PayNet's launch is 0.24 (0.30). Consistent with our assumption that the HHI captures the information structure of credit markets and that higher HHI reflects greater adverse selection, we find the relationship-switching rate in high HHI markets prior to PayNet is $2.0 \%$, statistically and economically lower than the $2.9 \%$ rate in low HHI markets. ${ }^{16}$

For each lender's home and new markets, we also measure the average delinquency rate as a proxy for credit risk and the average growth in aggregate credit. For the typical lender, the average delinquency rate across contracts in home (new) markets is $17 \%(16 \%)$. Growth in home (new) markets before entry averages $6 \%(2 \%)$.

We begin our analysis by examining how each lender's entry year varies by its home and new market concentrations. Figure 1 plots the pre-PayNet market concentrations for lenders (right-hand side y-axis) against the entry-year as well as the fraction of lenders entering in each year (left-hand side y-axis) from the launch of the bureau in 2001 to 2014, the end of our sample. For this figure, we measure market concentrations for each lender pre-PayNet, in early 2001, to capture the degree to which concentration in the absence of information sharing affects incentives to start sharing.

The figure shows that early entrants face low home market concentration and high new market concentration. These early entrants likely face stiff competition in their existing markets

\footnotetext{
${ }^{15}$ Alternatively, one could apply value-weighted HHIs. Unfortunately, no such weights exist for new markets, in which the lender has no exposure by design. Hence, we apply the same methodology of using equal weights for both home and new HHI. In unreported results, we confirm that results are similar if we use a value-weighted home HHI.

${ }^{16}$ Switching rates are defined as the average probability that a borrower stops contracting with a lender this quarter after contracting with them last quarter.
} 
but information asymmetry problems in accessing new markets, which implies they are the lenders with the most to gain from sharing information. This pattern is consistent with our theoretical discussion in Section 2. As the bureau grows, lenders with initial higher home market concentration and lower new market concentration join. In addition, the staggered timing of lender entry presented in Figure 1 indicates that bureau entry was unlikely due to a single credit event, business cycles, or growth in the equipment lending market.

To formalize the evidence from Figure 1, we estimate a model of lender entry. The dependent variable is Time to Entry, which measures the number of years from the current year until the year the lender enters the bureau. To illustrate, for a lender entering in 2005, Time to Entry equals two in 2003, one in 2004, zero in 2005, and is not recorded thereafter. We examine lenders in "event time" in this manner because it allows us to analyze how the post-PayNet variation in market, lender, and bureau characteristics explains entry. In particular, our tests allow us to estimate how the time to entry for each nonmember is affected by market concentrations, where concentrations are updated each year to account for how sharing by members impacts competition. In addition, tracking the Time to Entry for each lender allows us to include calendar year fixed effects to absorb common factors within each year, such as credit events or business cycles, that might explain entry. ${ }^{17}$ Standard errors are clustered at the lender level. We track our 207 sample lenders in each year from 1999 up to and including entry (years after entry are omitted), giving us 2,114 lender-year observations.

We model Time to Entry as a function of market, lender, and bureau characteristics. ${ }^{18}$ For home and new market characteristics, we measure the HHI, average delinquency rate across contracts, and aggregate market growth rate. For lender characteristics, we study the

\footnotetext{
${ }^{17}$ An alternative approach would be to include a single observation per lender, with the dependent variable being the years to entry from the start of our sample and all independent variables measured pre-PayNet. However, this would introduce measurement error by ignoring the effects of PayNet participation on market concentration and our other variables.

${ }^{18}$ To facilitate interpretation, we estimate the model using an OLS specification. Results are similar using a proportional hazard model.
} 
degree of specialization in collateral types (Log Collateral Types), lender size (Log Credit), mix of lease and loan contracts (Lease Share), and geographic scope (Log Regions) during the year. Last, to model coordination among lenders, we develop a lender-specific measure of the number of bureau members with exposures in the lender's home markets (Log Member Count).

In column 1 of Table 2, we include only the home and new market concentrations of each lender. In line with the unconditional analysis presented in Figure 1, the conditional results show that lenders with highly concentrated home markets, where the costs to sharing information are arguably higher, enter later (the coefficient on Home Market HHI is positive and significant). Those facing highly concentrated new markets, where the benefits of accessing shared information are arguably higher, enter earlier (New Market HHI is significantly negative).

Next, in columns 2 and 3, we examine how delinquencies and credit growth in the two kinds of markets affect entry. We find that lenders join earlier when new markets have higher delinquency rates, consistent with entrants facing greater adverse selection, due to incumbents' proprietary information on "bad" borrowers. Similarly, entry is delayed for lenders with higher growth in new markets, where entrants face lower adverse selection. In other words, lenders join sooner when adverse selection problems are most severe. Together, the results in columns 1-3 imply that lenders share information when the benefits of reducing adverse selection in new markets are greater than the costs of increased competition in their existing markets. ${ }^{19}$

In column 4, we introduce lender characteristics, measured as the average during the year for each lender. The results on home and new market concentration continue to hold. The coefficients of 1.613 and -36.108 on Home Market HHI and New Market HHI, respectively,

\footnotetext{
${ }^{19}$ An alternate hypothesis is that lenders in concentrated home markets should enter sooner because they can retain clients and protect rents, despite information sharing, while still gaining access to new markets. Then, one should expect a negative coefficient on both Home Market HHI, counter to our results. Thus it is unlikely that our results are driven by lenders joining earlier when they can protect rents in concentrated markets. Reinforcing this point, Sutherland (2018) finds that borrower switching rates increase significantly with information sharing, implying that client retention is not assured post information sharing.
} 
imply that a one standard deviation increase in Home (New) Market HHI delays (accelerates) entry by 0.2 (1.5) years. Furthermore, those entering earlier tend to be larger, lend against multiple collateral types, and contract more using leasing. Combined with our findings on home market concentration, this evidence is consistent with lenders entering earlier when they have less private information to protect. By comparison, lenders with monitoring technology that relies upon private information, such as specialist lenders that focus in fewer collateral markets and lenders contracting less using leasing, join later.

Heterogeneity in market and lender characteristics alone may not explain entry decisions. Decisions may also be linked to the depth of bureau coverage if lenders fear that coverage can result in market segmentation. Similarly, the decision to join may be correlated with the breadth of lenders in the bureau if, as the bureau succeeds, membership improves the reputation of lenders.

These mechanisms imply that lender entry should be positively correlated with the breadth of the bureau, because the costs of not being a bureau member increase as competitors join. In column 5 of Table 2, we examine this by including a lender-specific measure of the number of bureau members that year. Our measure considers only the number of members in the lender's home market and takes the average if the lender has than one home market. The results show that lenders are more likely to enter sooner as bureau membership increases, consistent with lenders responding to each other's actions. Our finding that entry is explained by concentration in existing and new markets continues to hold.

We conduct a series of robustness tests in Table A2 of the online appendix to reinforce our findings. First, we drop lenders joining before 2004 to examine whether the entry dynamics we document endure beyond the first movers to join PayNet. Column 1 shows that our inferences are similar. Second, we conduct a placebo analysis where we counterfactually assign random entry years to lenders and report average coefficients from 1,000 trials in column 2 . 
We find that none of our coefficients are significant. Third, we employ alternative classifications of home and new markets, by assessing lender exposures as of the second quarter of 2001 (the quarter before the bureau launched). Column 3 shows that our results hold. ${ }^{20}$

In summary, we provide evidence that, when deciding to share information, lenders trade-off a reduction in adverse selection in potential markets against heightened competition in existing ones.

\section{Information Sharing Effects on Lending}

\subsection{Descriptive Evidence on Lender Exposure Dynamics}

We build upon our bureau entry analysis by studying lenders' portfolios after sharing information. First, using a simple event study, we examine how the lenders' portfolios change after information is shared by tracking each lender before and after they join. The goal of this analysis is to offer descriptive evidence on whether lenders increase credit and enter new markets post information sharing. Of course, these results will reflect both the decision to share information and the effects of information sharing, but they are useful to gauge the overall changes in lending.

We construct a lender-quarter panel where the event time $t=0$ is measured as the last day of the quarter before the quarter in which each lender joins the bureau. The event window includes four quarters before and four quarters after the entry. This narrow window helps isolate the effects of information sharing from market-wide and lender-specific developments unrelated to information sharing.

We estimate:

\footnotetext{
${ }^{20}$ Finally, we address the concern that entry is clustered by region or collateral type, say, because of region or collateral type-specific growth. First, although our tests control for growth in the lender's home and new markets, we study the mean entry time by lenders in each region and collateral type and find no obvious pattern. Second, we repeat our tests with fixed effects for the collateral type and region in which the lender has the most exposure and find our results hold.
} 


$$
y_{i, t}=\alpha_{i}+\alpha_{t}+\beta \times \text { Member }_{i, t}+\varepsilon_{i, t},
$$

where $y_{i, t}$ is the log exposure measure for lender $i$ at event time $t$, measured in quarters around bureau entry. For each lender-quarter, exposure measures comprise the dollar amount of credit and number of collateral type-region markets in the portfolio. Member is a dummy variable equal to one for observations after the lender has joined the bureau. $\alpha_{i}$ and $\alpha_{t}$ are lender and time fixed effects, respectively. We cluster standard errors by lender.

We present the results from estimating (1) in Table 3. In column 1, we find that lenders significantly increase the amount of credit granted upon entering the bureau. Portfolio credit increases by $22.1 \%$ from the year before to the year after entry. Column 2 reveals lenders increase the number of markets (i.e., collateral type-region exposures) by $8.5 \%$. Of course, this descriptive analysis is not designed to account for selection into voluntary sharing.

\subsection{Information Sharing and Lender Exposure Dynamics}

\subsubsection{Empirical Specification}

Our exposure tests exploit variation in information coverage stemming from other members entering the bureau to examine how members expand credit in existing and new geographic markets within their specialization in collateral. We model lender exposures within collateral type-region as a function of the information coverage in the bureau, which a lender observes only after becoming a member. Specifically, we examine whether a member's credit exposure to a collateral type-region responds to changes in the stock of information shared in the bureau for the same collateral type-region and compare this response with that of nonmembers, who should not be directly affected by the information shared in the bureau. ${ }^{21}$

The empirical design mitigates concerns that voluntary entry by a lender is endogenous, by exploiting the staggered voluntary entry of other lenders to the bureau to provide exogenous

\footnotetext{
${ }^{21}$ Studying credit exposure and coverage at the collateral type rather than collateral type-region level produces the same inferences.
} 
variation in the information available to current members. ${ }^{22}$ This allows us to examine whether a lender's change in exposure in a market follows from a specialization in a specific collateral type and a shock to bureau coverage for that market, and not to either the decision to enter the bureau or growth in the number of bureau contracts per se.

The specification is:

$$
y_{i, j, r, t}=\alpha_{i, j}+\alpha_{i, t}+\alpha_{j, r, t}+\gamma \times \text { Member }_{i, t} \times \text { Coverage }_{j, r, t}+\varepsilon_{i, j, r, t},
$$

where the unit of observation is at the lender-collateral type-region-quarter level. Because we focus on the degree to which information sharing results in expansion within a lender's specialization, we condition on the collateral types each lender was exposed to when first appearing in the data. ${ }^{23} y_{i, j, r, t}$ is the log dollar amount of credit that lender $i$ has in collateral type $j$ in region $r$ in quarter $t . \alpha_{i, j}$ are lender-collateral fixed effects, which allow us to estimate exposure changes within a lender-collateral type offering. $\alpha_{i, t}$ are lender-quarter fixed effects, which absorb a lender's average growth in lending across all markets each quarter, including the average effect of a lender's decision to participate in the bureau as well as lender-level supply shocks affecting performance, capitalization, or the management team. $\alpha_{j, r, t}$ are collateral type-region-quarter fixed effects, which account for demand shocks occurring at the collateral type-region level. Member $_{i, t}$ is defined above. Coverage $e_{j, r}$ is the log number of contracts recorded in the bureau for collateral type $j$ in region $r$ in quarter $t$, excluding a lender's own contracts.

\footnotetext{
${ }^{22}$ The voluntary information sharing setting with staggered entry is similar to a sequential game, whereby lenders may join anticipating strategic entry from competing lenders. However, the staggered entry provides plausibly exogenous variation because lenders remain anonymous in the bureau, and lenders do not know which competitors will enter or when they will enter when making their own entry decision.

${ }^{23}$ There are two further motivations for conditioning on the lender's initial collateral exposures. First, including new collateral exposures, which by construction have zero initial credit, would bias our tests in favor of post-entry expansion. Second, defining our sample this way allows us to separately study expansion along intensive (Tables 4-5) and extensive (Table 7) margins with respect to collateral.
} 
To illustrate the variation in coverage that we shall exploit in specification (2), Figure 2 plots the growth in bureau coverage for the five most common collateral types. Although the bureau naturally grows over time, we note these five types experience coverage shocks at different points - the across-type correlation is just 0.33. Together with lenders' staggered entry presented in Figure 1, this evidence highlights the rich variation in coverage — both in the time series and the cross-section across collateral types-we exploit in our tests.

Several aspects of our research design warrant emphasis. If a lender's entry decision is correlated with its overall credit expansion, this would be estimated by the coefficient on Member $_{i, t}$, which is absorbed by the lender-quarter fixed effects. Similarly, if bureau coverage is correlated with credit demand in a collateral type-region, this effect on lending would be estimated for both members and nonmembers by the coefficient on Coverage $_{j, r, t}$, which is absorbed by the collateral type-region-quarter fixed effects. Thus, to the extent that lenders specializing in the same collateral type-region market face the same demand for credit, independent of their joining decision, the coefficient $\gamma$ identifies the effect of information sharing on a member's credit exposure.

Next, we focus on expansion into new collateral markets and examine whether collateral expertise can explain expansion into related collateral types. In other words, rather than focus on expansion along the intensive margin of collateral specialization as in (2), we examine the expansion along the extensive margin. Specifically, we model the exposure in a new collateral type as a function of how related a lender's existing collateral specialization is to the new collateral type. We develop a pairwise relatedness index capturing how similar two collateral types are in terms of specialization and the technology involved with contracting in those collateral types. We detail the construction of our relatedness index in Appendix B. Our tests estimate a specification similar to (2): 


$$
\begin{gathered}
y_{i, j, t}=\alpha_{i, j}+\alpha_{i, t}+\gamma \times \text { Member }_{i, t} \times \text { Relatedness }_{i, j}+\delta \times \text { Member }_{i, t} \times \text { Relatedness }_{i, j} \times \\
\text { Coverage }_{j, t}+\varepsilon_{i, j, t}, \quad \text { (3) }
\end{gathered}
$$

where the unit of observation is at the lender-collateral type-quarter level. To focus on the extensive margin, we restrict the sample to collateral types that the lender was not exposed to when they first appear in the data. $y_{i, j, t}$ is the log dollar amount of credit that lender $i$ has in collateral type $j$ in quarter $t$. Relatedness $s_{i, j}$ captures the maximum relatedness between lender $i$ 's home collateral types and new collateral type $j . \alpha_{i, j}$ and $\alpha_{i, t}$ are lender-collateral and lenderquarter fixed effects, respectively. If information sharing enhances the lender's ability to enter related markets when expanding their collateral offerings, we expect the coefficient $\delta$ to be positive.

\subsubsection{Lender Exposures within Collateral Specialization and Shocks to Coverage}

Table 4 studies how lender exposures are affected by bureau membership and information coverage. As an initial step, we use a modified version of equation (2) that includes lender-collateral, lender-quarter, and region-collateral fixed effects. Including regioncollateral, instead of region-collateral-quarter fixed effects, controls for time-invariant market demand for credit but not demand shocks that might be correlated with coverage. Hence, we can estimate the individual effect of Coverage on credit exposure, which represents the effect of coverage on exposure for nonmembers. This falsification test provides support for interpreting Coverage as a shock to information sharing in our empirical methodology.

In column 1, we find an insignificant coefficient on Coverage, suggesting that, for nonmembers, lending within a market is insensitive to the stock of bureau credit files for that market. We find a positive and significant coefficient on Member $\times$ Coverage $(10.5 \%)$. Next, we estimate equation (2) by adding region-collateral-quarter fixed effects. In column 2, we show that our results are robust to this specification. Changes in bureau coverage for a given 
collateral type-region lead to lender increases in exposure in that same collateral type-region. ${ }^{24}$ Economically, a one standard deviation increase in Coverage within a collateral type-region results in a $7.4 \%$ increase in credit within that collateral type-region for members. ${ }^{25}$

We then perform a series of robustness tests using the specification from column 2 of Table 4. The results are presented in Table A4 of the online appendix. First, to establish that our Table 4 results arise from information coverage in the lender's collateral specialization, we conduct a placebo test. Rather than measure the stock of information as the log number of bureau contracts for a given collateral type, we use Coverage Placebo, equal to the log number of all bureau contracts excluding that collateral type. If the exposure changes we document in Table 4 arise spuriously and are unrelated to improved screening and monitoring using bureau files, then we should continue to find a significant coefficient on the interaction term. Likewise, if lenders can expand without collateral-specific information, then their exposures could respond to increases in coverage of other collateral markets. Column 1 shows no postmembership credit expansion resulting from changes in Coverage Placebo. This reinforces that our findings are indeed driven by the availability of credit files for a given collateral type.

Second, we modify our Coverage variable to include stale contracts, defined as only contracts that were open four quarters ago (Stale Coverage). Lenders may find stale contracts useful for informing expansion, albeit less useful than contracts open today. Column 2 shows that the coefficient on Member $\times$ Stale Coverage is approximately $27 \%$ weaker than the original interaction term from Table 4, column 2. This is consistent with the availability of timely exposure-specific coverage driving the expansion in our tests.

\footnotetext{
${ }^{24}$ In Table A3 of the online appendix, we repeat our tests using alternative exposure measures: the number of contracts and number of states for the lender in the collateral type-region. Because census regions comprise six states on average, the number of state exposures within a region can change over time for individual lenders. We arrive at the same inferences using these measures.

${ }^{25}$ We multiply the 0.115 coefficient on Member x Coverage by the 0.64 standard deviation in Coverage, measured within collateral type-region.
} 
Third, to ensure our results are not solely driven by the largest lenders, which comprise a disproportionate share of our lender-collateral type-region-quarter observations, we repeat our tests after omitting these lenders. Column 3 shows our results are the same when we exclude the five largest lenders by total credit-using other thresholds (e.g., 10 lenders) produces the same inference. Last, we consider whether our results are concentrated in the early years of the bureau. Parallel to our Table A2, column 1 tests, we separate early joiners (those sharing in 2003 or earlier) from those that join later. Columns 4 and 5 show comparable results across these groups.

\subsubsection{Lender Exposures and Barriers to Entry}

Having established the robustness of our results, we now perform cross-sectional tests according to whether the collateral type-region markets are new to the lender, and the degree of concentration in these markets. The hypothesis, based on our bureau entry analyses, is that the lending response to bureau information coverage should be strongest for new markets, and within these markets strongest for those with high concentration.

Once again, we employ the specification presented in column 2 of Table 4, where we examine lending at the collateral type-region-quarter level and condition on expansion within collateral types that lenders contract in prior to joining the bureau. As in Table 2, home and new markets are classified according to whether the lender contracts in them (home) or not (new) prior to sharing. Finally, for each lender, we split its markets into four groups: home markets with low HHI, new markets with low HHI, home markets with high HHI, and new markets with high HHI.

Table 5 presents the results. We find credit expansion using shared information is focused in new markets, especially those with high concentration. We find no statistical expansion related to information coverage in home markets. This complements our entry 
analysis finding that lenders' incentives to share information are positively related to New Market HHI.

Overall, our results on lending dynamics present evidence that lenders offer more credit after joining the bureau. Information sharing and collateral specialization are central to this expansion. Bureau member exposures to a collateral type evolve with shocks to bureau coverage for that collateral type, while nonmembers experience no such change. Exposure growth is concentrated in a lender's new markets, especially those where information sharing alleviates adverse selection problems.

\subsubsection{Lender Exposures in New Collateral Types and Shocks to Coverage}

Our tests so far study how lenders expand within their existing collateral markets upon entering the bureau. Next, we examine whether lenders enter new collateral markets, given their expertise and the bureau coverage for the new markets.

One possible expansion strategy is for the lender to enter new collateral markets that share features with their existing ones. For example, computers and copiers likely involve a similar set of vendors, borrowers, and approaches to screening and monitoring. On the other hand, there is less overlap in lending technology between computers and logging or railroad equipment. Our hypothesis is that a lender first exposed to copiers, for example, is more likely to expand into computers than into railroad equipment after joining the bureau and that information coverage aids such expansion.

To understand the degree to which lending technologies are common across collateral types, we develop an index of collateral type relatedness, following Teece et al. (1994) and Bryce and Winter (2009). For each pair of possible collateral types, we first count the number of lenders contracting in both. This count variable reveals the frequency with which collateral types overlap in lenders' portfolios. Second, we adjust the count measure for the probability of overlap we would observe if collateral types were randomly allocated to lenders, given the 
number of lenders and the observed quantities of each collateral type in the market. Third, we control for the dollar values of contracts to account for the fact that collateral types may not be related if, though observed together frequently, they comprise only a small fraction of a lender's portfolio, on average. Fourth, we allow for indirect relatedness by translating relatedness to a distance and applying a shortest path algorithm. In other words, two collateral types, A and B, may be rarely observed together in a lender's portfolio but each may be highly related to a third collateral type, $\mathrm{C}$, which means that $\mathrm{A}$ and $\mathrm{B}$ are also related. Finally, we convert the distance measure back into a standardized relatedness measure by subtracting the mean and dividing by the standard deviation. ${ }^{26}$ Appendix B explains the construction of the index in detail.

Our tests consider the maximum pairwise relatedness between the lender's current collateral types and a given new collateral type for the lender. Appendix C presents summary statistics for our relatedness index. Although our tests use the standardized relatedness measure, we present percentiles in this appendix to facilitate interpretation.

Our index produces pairwise similarity scores that capture underlying similarities in collateral features. For example, computers and copiers are scored as highly related (99.3), while railroads and copiers are not (15.9). Moreover, within a collateral type, our index scores high in comparable related assets (e.g., for computers, the highest relatedness scores are assigned to telecommunications, copier and fax, and office equipment). Table 6 summarizes the most related collateral type pairs in our sample.

Table 7 presents the results on expansion into related collateral types using specification (3). Column 1 shows that, on average, lenders are more likely to expand in related new collateral types than unrelated ones. The positive and significant coefficient on Relatedness of 0.912 implies that, unconditionally, credit increases by 91 percent more, on average, in new

\footnotetext{
${ }^{26}$ We find similar results if we ignore contract amounts or do not allow for indirect relatedness when constructing the index.
} 
related collateral types than new unrelated types, for a one standard deviation change in Relatedness across collateral types (given Relatedness is standardized and has a standard deviation of one). This relation strengthens after the lender enters the bureau. The positive coefficient on Member $\times$ Relatedness of 0.767 , combined with the 0.912 coefficient on Relatedness, implies that for a one standard deviation increase in Relatedness, members increase credit by 168 percent more in a new related collateral type than a new unrelated type. Thus the results show that not only are lenders more likely to enter related than unrelated collateral markets at the extensive margin but that this preference strengthens, post information sharing, once lenders face lower adverse selection.

In column 2, we add lender-collateral type fixed effects and obtain similar results. The effect on information sharing at the extensive margin is to increase new market entry into related collateral markets by 65 percent, relative to new market entry into unrelated collateral markets. Given our lender-collateral type and lender-quarter fixed effects, this stronger expansion into related collateral types cannot be explained by lender-level business model shifts or time-invariant features of individual lenders' collateral offerings.

Column 3 retains the same fixed effect structure as column 2 and introduces our Coverage variable to link collateral market expansion to bureau coverage ${ }^{27}$ Interestingly, the coefficient on Member $\times$ Relatedness itself is no longer significant. Instead, expansion into related new collateral types in the post-period is primarily moderated by the availability of credit files in that collateral type. (Member $\times$ Relatedness $\times$ Coverage is positive and significant.) These results complement our earlier findings. Lenders' collateral expertise influences their expansion into new collateral markets, and expansion efforts rely upon bureau coverage.

\footnotetext{
${ }^{27}$ To ease interpretation, Coverage is expressed as a proportion (between 0 and 1) of the maximum all time coverage for each collateral type. Using the raw measure does not affect our inferences.
} 


\subsection{Information Sharing, Exposures, and Lending Technology}

The results on entry timing presented in Table 2 show that lending technology is key to understanding the decision to share information. In particular, lenders that rely more on private and soft information, are specialized, and operate in few markets face different costs and benefits from information sharing than their larger, less focused counterparts.

Next, we study whether differences in lender size and focus affect the response to new information. On one hand, large lenders may not only be better able to exploit hard information shared in the bureau but also may want to access information on small borrowers from small lenders, since small lenders have an advantage in collecting private and soft information (Stein 2002; Berger et al 2005; Liberti and Mian 2009; Loutskina and Strahan 2011). On the other hand, smaller and focused lenders may benefit from access to information on markets in which they have no presence or information collection technology.

In Table 8, we examine how the information sharing effects on lender exposures vary by lender size and collateral focus. We employ specification (1), which examines differences in lenders' overall exposures around bureau entry, because we want to capture the full effect of how information sharing affects a lender's portfolio. The dependent variable is the log of dollar credit in the lender's portfolio or the lender's exposure to small clients in Panels A and B, respectively. Large Lender is an indicator variable equal to one for lenders with abovemedian credit in the quarter before entry; \#Collateral Types counts the log number of unique collateral types the lender contracts in before entry.

The results in Column 1 of Panel A show that lenders, on average, increase credit after becoming members. Column 2 introduces an interaction between Member and Large Lender and finds that smaller lenders drive the credit expansion we document (though the $10.8 \%$ change in Log Credit for large lenders is statistically significant). Column 3 studies collateral focus and finds credit expansion is decreasing in the number of collateral exposures for the 
lender (i.e., focused lenders expand credit more than diversified lenders). Column 4 includes interactions for both lender size and collateral focus and arrives at similar conclusions. Column 5 saturates the regression with year $\times$ lender size and year $\times$ collateral focus categories (defined at the median). Doing so reduces concerns that our findings come from size or focus-specific trends being correlated with bureau entry. Our results are similar.

In Panel B of Table 8, we study the share of the lender's borrowers classified as small. We define Small Clients as a dummy variable equal to one for borrowers in the bottom quartile of total credit measured at the collateral type-quarter level. We then measure the percentage of the lender's clients classified as small firms in each quarter. The results in column 1 show that, on average, small client exposure does not increase post joining the bureau. However, when we condition on lender size in column 2 , the results reveal that larger lenders increase exposure to small borrowers by $2.5 \%$ more than smaller lenders. This is economically significant, when compared with the average pre-entry allocation of $19.1 \%$ to small firms by large lenders. By contrast, we find no relation between small client exposure, bureau membership, and lender collateral focus.

Overall, these results indicate that conditional on joining, small lenders have the most to gain in terms of lending growth and that although large lenders see modest growth in their portfolio, they benefit by contracting more with small borrowers. Combined with the results in Table 2, where we show that small specialized lenders enter later, these results imply that small specialized lenders face both larger costs and benefits to sharing than other lenders and hence once they overcome the costs of sharing, they benefit more.

Finally, the results also imply that information sharing increases competition for financing small borrowers, which arguably face the greatest barriers to accessing credit in the absence of information sharing.

\subsection{Information Sharing and Borrowers' Credit Relationships}


Our final set of tests examines contracting from the borrower perspective. We study how the number of lending relationships and credit outstanding for each borrower changes after they first have a credit file in PayNet (Post File). Two features of our tests provide for reliable estimates of the effect of information sharing on borrowers' activities. First, lenders, not borrowers, decide to enter the bureau, so entry is exogenous to the borrower. Second, the micro unit of analysis allows us to control for industry-quarter fixed effects to account for contemporaneous changes in demand for credit within a sector, and borrower fixed effects to account for time-invariant firm characteristics. ${ }^{28}$

Column 1 of Table 9 shows that the number of lending relationships for the average borrower increases by $6.0 \%$ in the post period. Economically, there is a one-sixth reduction in the share of borrowers with just one lending relationship. Next, we examine the effect on total borrowing. Column 2 shows a statistically and economically significant increase in total credit of $11.8 \%$. Our results build upon the survey evidence documenting improved access to finance following the introduction or reform of credit bureaus in developing countries (Brown et al. 2009; Love et al. 2013; Peria and Singh 2014).

Finally, we examine whether the timing of credit access changes with file availability. To do this, we create an indicator variable measuring when firms are borrowing. This variable is equal to one if the firm started a new lending relationship without having an old contract maturing that quarter or a surrounding quarter. The intuition for this "off cycle" variable is that not being tied to the maturity cycle of current contracts provides financial flexibility for the borrowers. Column 3 shows that access to finance significantly improves once credit files are available. The likelihood of starting a new relationship off cycle increases by $0.7 \%$, representing $5 \%$ of the pre-period mean.

\footnotetext{
${ }^{28}$ We control for industry, rather than collateral type, effects here because many borrowers have more than one collateral type.
} 
Overall, our results show that information sharing improves access to specialized lenders, suggesting that voluntary sharing also enhances a borrower's access to credit. Thus, our findings contribute to a growing literature exploring the impact of credit scores and information sharing on credit markets. ${ }^{29}$ In addition, our results help rule out an alternate motivation for information sharing: collusion among lenders to protect their own rents.

\section{Conclusion}

We provide evidence that developments in technology that facilitate information sharing can change the competitive landscape of lending. We offer the first direct evidence on the trade-offs behind voluntary information sharing and how lenders share information to overcome adverse selection problems in new markets.

Our findings help illuminate voluntary information sharing in financial markets and explain why intermediaries regularly forego rents when sharing. Our results highlight that, while adverse selection protects incumbents, lenders willingly share information to overcome information asymmetries impeding access to new markets.

Rather than diversify, we find that lenders expand within their collateral expertise, suggesting that information sharing also provides better access to borrowers by specialized lenders. In addition, technology that allows for the transfer of private information or hardening of soft information, reduces the need of lenders to collect this information and potentially reduces hold-up problems associated with SME financing.

Our study is also important for understanding the role of fintech in credit markets. Early literature mostly focused on fintech as an incubator for new lenders and how these new lenders compare with traditional lenders, especially in terms of efficiency (Philippon 2015) or

\footnotetext{
${ }^{29}$ See, among others, Padilla and Pagano (2000), Jappelli and Pagano (2002), Musto (2004), Brown et al. (2009), Doblas-Madrid and Minetti (2013), Gonzales-Uribe and Osorio (2014), Bennardo et al. (2015), Paravisini and Schoar 2015, Balakrishnan and Ertan (2017), Giannetti et al. (2017), Liberti et al. (2017), and Sutherland (2018).
} 
regulation (Philippon 2016; Buchak et. al. 2017). We show that fintech can also affect competition, lender business models, and access to credit in traditional credit markets. These results are particularly relevant in light of the recent expansion of digital platforms in credit markets. For example, in early 2018, the European Commission unveiled a FinTech Action Plan as part of their efforts to build a Capital Markets Union. The Action Plan addresses 19 steps that focus on, among other initiatives, the digitization and sharing of credit information.

Finally, our results raise the possibility that some credit markets may not be appropriately served by lenders, absent sharing mechanisms. While voluntary information sharing arises endogenously in the market we study, sharing may not arise where costs to individual lenders outweigh the benefits of a reduction in adverse selection. Studying not only the market structure, as we do, but also how information is used in screening and monitoring will help illuminate the relative benefits of information sharing (Strahan 2017). We leave this for future research. 


\section{References}

Acharya, V. V., Hasan, I., \& Saunders, A. (2006). Should banks be diversified? Evidence from individual bank loan portfolios. Journal of Business, 79(3), 1355-1412.

Balakrishnan, K., \& Ertan, A. (2017). Credit information sharing, loan loss recognition timeliness, and financial stability. London Business School, working paper.

Basel Committee on Banking Supervision. 2000. Principles for the management of credit risk. Basel, Switzerland.

Benmelech, E., Garmaise, M., \& Moskowitz, T. (2005). Do liquidation values affect financial contracts? Evidence from commercial zoning laws. Quarterly Journal of Economics, 120.3, $1121-1154$.

Bennardo, A., Pagano, M., \& Piccolo, S. (2015). Multiple bank lending, creditor rights, and information sharing. Review of Finance, 19(2), 519-570.

Berger, P. G., \& Ofek, E. (1995). Diversification's effect on firm value. Journal of Financial Economics, 37(1), 39-65.

Berger, P. G., Minnis, M., \& Sutherland, A. (2017). Commercial lending concentration and bank expertise: Evidence from borrower financial statements. Journal of Accounting and Economics, 64(2-3), 253-277.

Boehm, J., Dhingra, S., \& Morrow, J. (2016) Swimming upstream: Input-output linkages and the direction of product adoption. LSE CEP Discussion Paper No 1407

Boot, A. W., \& Thakor, A. V. (2000). Can relationship banking survive competition? The Journal of Finance, 55(2), 679-713.

Boyd, J. H., \& Prescott, E. C. (1986). Financial intermediary-coalitions. Journal of Economic Theory, 38(2), 211-232.

Brown, M., Jappelli, T., \& Pagano, M. (2009). Information sharing and credit: Firm-level evidence from transition countries. Journal of Financial Intermediation, 18(2), 151-172.

Brown, M., \& Zehnder, C. (2010). The emergence of information sharing in credit markets. Journal of Financial Intermediation, 19(2), 255-278.

Bruhn, M., Fazari, S., \& Kanz, M. (2013). Bank competition, concentration, and credit reporting. World Bank WPS6442

Bryce, D. J., \& Winter, S. G. (2009). A general interindustry relatedness index. Management Science, 55(9), 1570-1585.

Buchak, G., Matvos, G, Piskorski, T., \& Seru, A. (2017). Fintech, regulatory arbitrage, and the rise of shadow banks. University of Chicago, working paper

Campa, J. M., \& Kedia, S. (2002) Explaining the diversification discount. The Journal of Finance 57(4), 1731-1762. 
Campbell, D., Loumioti, M., \& Wittenberg Moerman, R. (2017). Making sense of soft information: Interpretation bias and ex-post lending outcomes. Working paper.

Carey, M., Post, M., \& Sharpe, S. A. (1998). Does corporate lending by banks and finance companies differ? Evidence on specialization in private debt contracting. The Journal of Finance, 53(3), 845-878.

Chen, B. S., Hanson, S., \& Stein, J.C. (2017). The decline of big-bank lending to small business: Dynamic impacts on local credit and labor markets. Harvard Business School, working paper.

Conley, T. G., \& Dupor, B. (2003). A spatial analysis of sectoral complementarity. Journal of political Economy, 111, 311-352

Dell'Ariccia, G., Friedman, E., \& Marquez, R. (1999). Adverse selection as a barrier to entry in the banking industry. The RAND Journal of Economics, 515-534.

Dell'Ariccia, G. (2001). Asymmetric information and the structure of the banking industry. European Economic Review, 45(10), 1957-1980.

di Giovanni, J., Levchenko, A. A., \& Méjean, I. (2014). Firms, destinations, and aggregate fluctuations. Econometrica, 82(4), 1303-1340.

Diamond, D. W. (1984). Financial intermediation and delegated monitoring. Review of Economic Studies, 51(3), 393-414.

Djankov, S., McLiesh, C., \& Shleifer, A. (2007). Private credit in 129 countries. Journal of Financial Economics, 84(2), 299-329.

Doblas-Madrid, A., \& Minetti, R. (2013). Sharing information in the credit market: Contractlevel evidence from US firms. Journal of Financial Economics, 109(1), 198-223.

Eisfeldt, A. L., \& Rampini, A. (2009). Leasing, ability to repossess, and debt capacity. Review of Financial Studies, 22(4), 1621-1657.

Giannetti, M., Liberti, J. M. \& Sturgess, J. (2017). Information sharing and rating manipulation. The Review of Financial Studies, 30(9), 3269-3304.

González-Uribe, J., \& Osorio, D. (2014). Information sharing and credit outcomes: Evidence from a natural experiment. Mimeo.

Hauswald, R., \& Marquez, R. (2006). Competition and strategic information acquisition in credit markets. Review of Financial Studies, 19(3), 967-1000.

Jappelli, T., \& Pagano, M. (2002). Information sharing, lending and defaults: Cross-country evidence. Journal of Banking \& Finance, 26(10), 2017-2045.

Liberti, J. M., \& Mian, A. (2009). Estimating the effect of hierarchies on information use. The Review of Financial Studies, 22(10), 4057-4090. 
Liberti, J. M., \& Petersen, M. A. (2017). Information: Hard and soft. Northwestern University, working paper.

Liberti, J. M., Seru, A., \& Vig, V. (2017). Information, credit and organization. Stanford University, working paper.

Loutskina, E., \& Strahan, P. E. (2011). Informed and uninformed investment in housing: The downside of diversification. Review of Financial Studies, 24(5), 1447-1480.

Marquez, R. (2002). Competition, adverse selection, and information dispersion in the banking industry. The Review of Financial Studies, 15(3), 901-926.

Monitor. (2015). 2015 Monitor 100. Xander Media Group.

Murfin, J., \& Pratt, R. (2017). Who finances durable goods and why it matters: Captive finance and the Coase Conjecture. Yale University, working paper.

Musto, D. K. (2004). What happens when information leaves a market? Evidence from postbankruptcy consumers. Journal of Business, 77(4), 725-748.

Office of the Comptroller of the Currency. (2011). Comptroller's handbook: Concentrations of credit. Washington, D.C.

Padilla, A. J., \& Pagano, M. (1997). Endogenous communication among lenders and entrepreneurial incentives. Review of Financial Studies, 10(1), 205-236.

Padilla, A. J., \& Pagano, M. (2000). Sharing default information as a borrower discipline device. European Economic Review, 44(10), 1951-1980.

Pagano, M., \& Jappelli, T. (1993). Information sharing in credit markets. Journal of Finance, 48(5), 1693-1718.

Paravisini, D., Rappoport, V., \& Schnabl, P. (2015). Specialization in bank lending: Evidence from exporting firms (No. w21800). National Bureau of Economic Research.

Paravisini, D., \& Schoar, A. (2015). The incentive effect of scores: Randomized evidence from credit committees. NBER working paper.

Philippon, T. (2015). Has the US finance industry become less efficient? On the theory and measurement of financial intermediation. American Economic Review, 105, 1408-1438.

Philippon, T. (2016). The FinTech opportunity. NBER working paper 22476.

Rajan, R. G. (1992). Insiders and outsiders: The choice between informed and arm's-length debt. The Journal of Finance, 47(4), 1367-1400.

Rajan, R., Servaes, H., \& Zingales, L. (2000). The cost of diversity: The diversification discount and inefficient investment. The Journal of Finance, 55(1), 35-80.

Sharpe, S. A. (1990). Asymmetric information, bank lending, and implicit contracts: A stylized model of customer relationships. The Journal of Finance, 45(4), 1069-1087. 
Stein, J. C. (2002). Information production and capital allocation: Decentralized versus hierarchical firms. The Journal of Finance, 57(5), 1891-1921.

Strahan, P. E. (2017). Are concentrated banks better informed than diversified ones? Journal of Accounting and Economics, forthcoming.

Sutherland, A. (2018). Does credit reporting lead to a decline in relationship lending? Evidence from information sharing technology. Journal of Accounting \& Economics, forthcoming.

Teece, D., Rumelt, R., Dosi, G., \& Winter, S. (1994). Understanding corporate coherence: Theory and evidence. Journal of Economic Behavior \& Organization, 23(1) 1-30. (Reprinted with corrections in Alternative Theories of the Firm, Vol. II. R. N. Langlois, T. F.-L. Yu, P. Robertson, eds. Elgar, Cheltenham, UK, 2002.)

Vives, X. (1990). Trade association disclosure rules, incentives to share information, and welfare. the RAND Journal of Economics, 409-430.

Ware, T. (2002). The future of commercial credit data. Equipment Leasing Today, June/July, 22-29.

Winton, A. (1999). Don't put all your eggs in one basket? Diversification and specialization in lending. University of Minnesota, manuscript.

World Bank. (2016). Doing business 2016: Getting credit. Washington, DC: World Bank. 
Appendix A: Variable Definitions

\begin{tabular}{|c|c|}
\hline Variable & Definition \\
\hline Time to Entry & $\begin{array}{l}\text { The number of years from the current year, starting in } 1999 \text {, until } \\
\text { the year of bureau entry for the lender. The variable is recorded } \\
\text { as missing thereafter. }\end{array}$ \\
\hline Market & $\begin{array}{l}\text { A lending segment defined as the intersection of one of } 23 \\
\text { collateral types and one of nine U.S. census regions. }\end{array}$ \\
\hline Home Market & $\begin{array}{l}\text { Those collateral type-regions the lender competed in during its } \\
\text { first quarter in the data. }\end{array}$ \\
\hline New Market & $\begin{array}{l}\text { Those collateral type-regions the lender did not compete in } \\
\text { during its first quarter in the data. }\end{array}$ \\
\hline Home Market HHI & $\begin{array}{l}\text { The Herfindahl-Hirschman index for the lender's home markets. } \\
\text { The index is measured each year at the collateral type-region } \\
\text { level. If the lender competes in more than one market, we equal- } \\
\text { weight the HHIs to arrive at Home Market HHI. }\end{array}$ \\
\hline New Market HHI & $\begin{array}{l}\text { The Herfindahl-Hirschman index for the lender's new markets. } \\
\text { The index is measured each year at the collateral type-region } \\
\text { level. We equal-weight the HHIs to arrive at New Market HHI. }\end{array}$ \\
\hline Home Market Growth & $\begin{array}{l}\text { The change in total credit across all lenders in the lender's home } \\
\text { markets from last year to this year. We equal-weight the growth } \\
\text { rates across markets to arrive at Home Market Growth. }\end{array}$ \\
\hline New Market Growth & $\begin{array}{l}\text { The change in total credit across all lenders in the lender's new } \\
\text { markets from last year to this year. We equal-weight the growth } \\
\text { rates across markets to arrive at New Market Growth. }\end{array}$ \\
\hline $\begin{array}{l}\text { Home Market } \\
\text { Delinquency }\end{array}$ & $\begin{array}{l}\text { The proportion of all contracts in the lender's home markets that } \\
\text { are currently delinquent. }\end{array}$ \\
\hline $\begin{array}{l}\text { New Market } \\
\text { Delinquency }\end{array}$ & $\begin{array}{l}\text { The proportion of all contracts in the lender's new markets that } \\
\text { are currently delinquent. }\end{array}$ \\
\hline Log Markets & $\begin{array}{l}\text { The log number of markets (collateral type-region pairs) the } \\
\text { lender contracts in. }\end{array}$ \\
\hline Log Regions & The log number of census regions the lender contracts in. \\
\hline Log Collateral Types & The log number of collateral types the lender contracts in. \\
\hline Log Credit & $\begin{array}{l}\text { The log dollar value of all open contracts for the lender. For } \\
\text { leases, we sum the total required payments during the term of } \\
\text { the contract. }\end{array}$ \\
\hline
\end{tabular}




\begin{tabular}{|l|l|}
\hline Lease Share & The percentage of the lender's contracts that are leases. \\
\hline Log Member Count & $\begin{array}{l}\text { A lender-year measure of the number of current members of the } \\
\text { bureau. Each year, we count the number of members in each } \\
\text { market. Then, for each lender-year, we take the average number } \\
\text { of members across the lender's home markets. }\end{array}$ \\
\hline Member & $\begin{array}{l}\text { An indicator variable equal to one for all of the quarters after the } \\
\text { lender has joined the bureau and zero otherwise. }\end{array}$ \\
\hline Coverage & $\begin{array}{l}\text { The log number of open (i.e., pre-maturity) contracts contained } \\
\text { in the bureau for a given collateral type or collateral type-region. }\end{array}$ \\
\hline Relatedness & $\begin{array}{l}\text { A measure of the degree of similarity between two collateral } \\
\text { types. In our tests, we measure the maximum relatedness } \\
\text { between a new collateral type and the lender's existing collateral } \\
\text { offerings. Appendix B describes the construction of the } \\
\text { relatedness measure. }\end{array}$ \\
\hline Large Lender & $\begin{array}{l}\text { An indicator variable equal to one for lenders with above median } \\
\text { credit in the quarter before entering the bureau and zero } \\
\text { otherwise. }\end{array}$ \\
\hline Starts New Relationship \\
\hline Off Cycle
\end{tabular}




\section{Appendix B: Construction of the Collateral Type Relatedness Index}

The construction of the collateral type relatedness index is motivated by Teece et al. (1994) and Bryce and Winter (2009) and involves the following steps.

Step 1: Estimating the collateral type dyad count. We begin by observing how many times two collateral types (a collateral type dyad) are observed together in the same lender.

We start with $K=207$ lenders contracting in $I=23$ collateral types. Let $C_{i k}=1$ if lender $k$ contracts in collateral type $i$ and 0 otherwise. The number of lenders active in collateral type $i$ is $n_{i}=\sum_{k=1}^{k=207} C_{i k}$, and the number of lenders active in both collateral type $i$ and collateral type $j$ is $J_{i j}=\sum_{k=1}^{k=207} C_{i k} C_{j k}$.

Step 2: Estimating the collateral type dyad relatedness. Next, we scale the collateral dyad count to control for the observed frequency of each collateral type. Specifically, $J_{i j}$ cannot be taken directly as a measure of relatedness and must be adjusted for the number of lenders appearing in the dyad if lenders were randomly assigned to collateral types.

To measure the distribution of the collateral dyad, $X_{i k}$ consider the probability that $x$ out of $K$ lenders receive a random assignment to both collateral types $i$ and $j$. For this random model, we take the collateral type sizes $n_{i}$ and $n_{j}$ and the population size $K$ as given and ask how many times do the $n_{j} j$ 's overlap with the $n_{i} i$ 's consistent with the observed $x$.

i. Start with the $n_{j}$ lenders in collateral type $j$.

ii. $\quad$ From these $n_{j}$ lenders, allocate the $x$ lenders in the overlap with collateral type $i$ to $x$ of the $n_{i}$ observations. This can happen in $\left(\begin{array}{c}n_{i} \\ x\end{array}\right)$ ways.

iii. Allocate the remaining $n_{j}-x$ lenders that are in collateral type $j$ to the $K-n_{i}$ lenders not in the overlap. This can happen in $\left(\begin{array}{l}K-n_{i} \\ n_{j}-x\end{array}\right)$ ways.

iv. Normalize the sorts in (ii) and (iii) by the total number of ways the $n_{j}$ lenders can be sorted, i.e., the number of ways one can choose $n_{j}$ lenders from $K$ lenders, $\left(\begin{array}{c}K \\ n_{j}\end{array}\right)$.

Then the probability of observing an overlap of $x$ is given by the hypergeometric random variable:

$$
P\left[X_{i j}=x\right]=\frac{\left(\begin{array}{c}
n_{i} \\
x
\end{array}\right)\left(\begin{array}{c}
K-n_{i} \\
n_{j}-x
\end{array}\right)}{\left(\begin{array}{l}
K \\
n_{j}
\end{array}\right)},
$$

with a mean of:

$$
\mu_{i j}=E\left(X_{i j}\right)=\frac{n_{i} n_{j}}{K}
$$

and variance of:

$$
\sigma_{i j}^{2}=\mu_{i j}\left(1-\frac{n_{i}}{K}\right)\left(\begin{array}{c}
n_{i} n_{j} \\
K
\end{array}\right)
$$


We can now compare the observed dyad $J_{i j}$ with the expected dyad, $E\left[X_{i j}\right]$, by estimating the standardized dyad:

$$
\tau_{i j}=\frac{J_{i j}-\mu_{i j}}{\sigma_{i j}}
$$

When the $\tau_{i j}$ is positive and large, it indicates systematic exposure by lenders into pairs of collateral types. That is, types are related if lenders finance collateral types that share similar monitoring technologies.

Step 3: Estimating the weighted collateral type dyad relatedness. A shortfall of the standardized measure estimated in step 2 is that it does not reflect the economic importance of the dyad frequency of collateral types within a lender. For example, two activities each contributing only $1 \%-2 \%$ of the lenders' contract pool may be only weakly related, whereas two collateral types that each secure close to half of the contract pool are likely related more strongly. If the pattern is consistent across all lenders operating in two collateral types, then this should be reflected in the relatedness score of the dyad.

We account for the dyad weights as follows. The weight is determined by comparing for each dyad the relative weights, $s_{i}$ and $s_{j}$, of total contract pool that are attributable to each activity $i$ and $j$ of the dyad. The minimum of these two weights, $\min \left[s_{i}, s_{j}\right]$, is then selected for each lender and averaged across all lenders operating in the dyad. The minimum weight is selected because it represents an "upper bound" measure of how closely related the two industries could be when they appear together. If collateral type A, having a weight of 0.01 , is combined with collateral type $\mathrm{B}$, having a weight of 0.70 , the 0.01 is selected to provide information on the importance of the dyad to that lender. These minimum weights are then averaged across all lenders operating in the dyad to create the dyad weight.

The average weight $S_{i j}$ produced by all lenders operating in the dyad is

$$
S_{i j}^{\min }=\frac{\sum_{k} \min _{k}\left[s_{i}, S_{j}\right] C_{i k} C_{j k}}{\sum_{k} C_{i k} C_{j k}}
$$

To adjust the standardized measures by the weight, the scores in (4) are first converted to a distance matrix such that all measures are positive and a smaller measure reflects high relatedness. The distance matrix is computed by identifying the maximum $\tau_{i j}$ among the set of normalized scores and subtracting all scores from this value.

Following this transformation, cell values in the distance matrix are divided by (5), such that those dyads with a small weighting are transformed to be "more" distant. The resulting matrix can be evaluated as a network in which the values in matrix cells are the distances between nodes $i$ and $j$. The network is comprised of collateral type vertices connected by arcs having weight (length) inversely proportional to relatedness.

\section{Step 4: Estimating relatedness using shortest paths}

The weighted distance measure in step 3 allows only for direct relatedness and not indirect relatedness. For example, consider that collateral types $x$ and $y$ have distance " 2 " and $y$ and $z$ 
have distance " 3 ," and the distance for $x$ and $z$ is unobserved. To account for this, we employ a shortest path measure, which implies that $x$ and $z$ must have a distance of 5 .

The shortest path method produces a distance measure for dyads that are not directly connected in the network, and it substitutes a shortest path distance for a direct link between two collateral types when the path distance is shorter than the direct distance.

To complete construction of the index, the weighted distance matrix, which is now filled with shortest path scores, is converted to a similarities matrix, where the greatest values, rather than the lowest values, represent the highest relatedness. This is done simply by subtracting each computed path length score from the maximum computed path length, which implicitly sets the least related dyad to a value of zero and the most related dyad to some positive value. Following the similarities transformation, index scores are transformed to have a mean of 0 and a standard deviation of 1 . Specifically, the similarity score is standardized by subtracting the mean of the distribution from each value and dividing by the standard deviation.

Plots of the distribution of all normalized (not percentile) dyad relatedness index scores are presented in Appendix C. 


\section{Appendix C: Collateral Type Relatedness Index}

The table presents relatedness scores for collateral type pairs from the 207 lenders observed in the sample. Relatedness scores are distributed approximately normally. Normalized values, or z-scores, range from a low of -2.45 to a high of 2.64 standard deviations from the mean. To facilitate interpretation, the relatedness scores have been transformed into a percentile that represents the cumulative area under the distribution and ranges between 0 and 100. An index score of 70 implies that $70 \%$ of collateral type dyads are less related than the focal score, whereas $30 \%$ are more related.

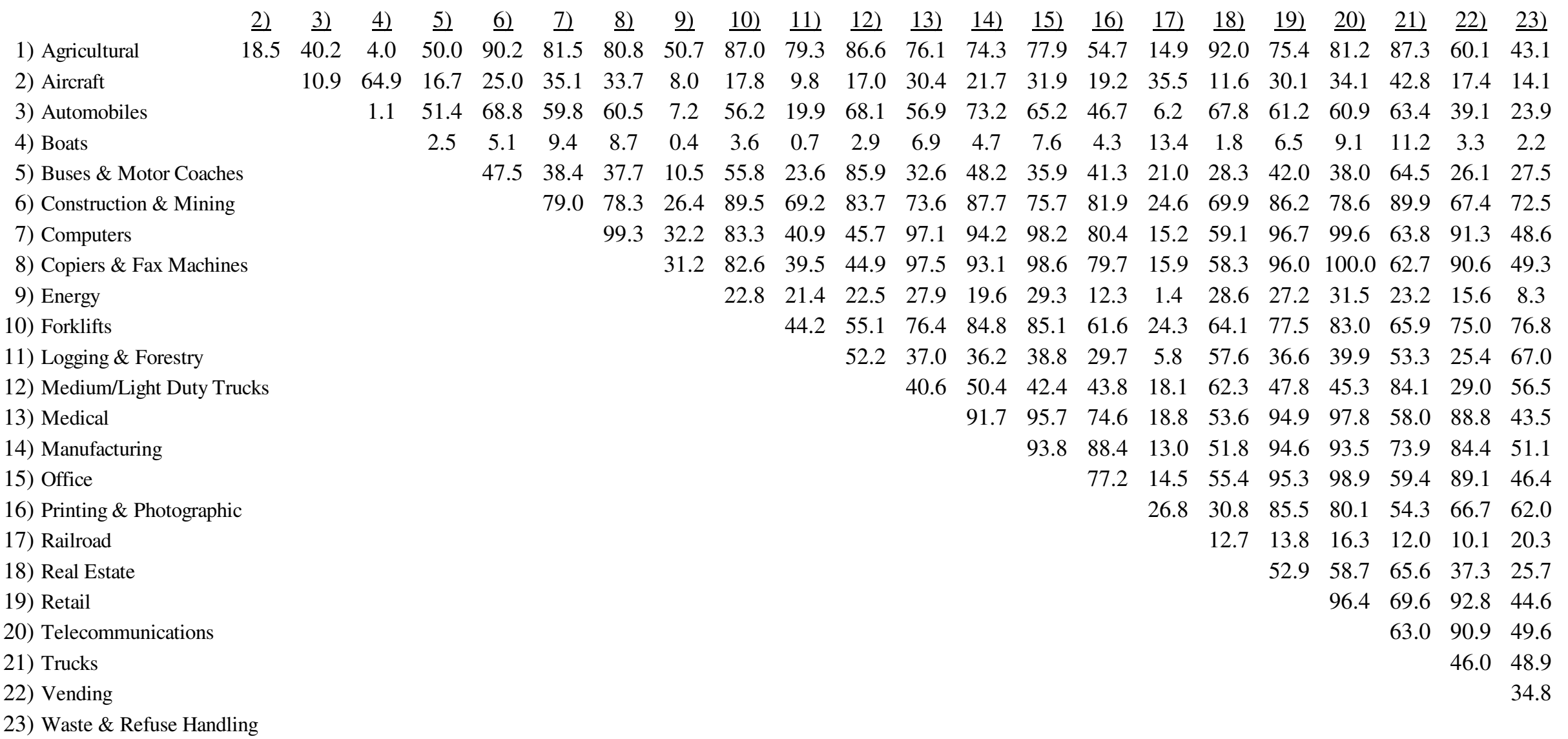




\section{Figure 1: Bureau Entry Timing and Market Concentration}

This figure plots the timing of lenders' bureau entry as a function of home and new market concentration. The left (right) axis measures the fraction of lenders entering the bureau that year (Home and New Market HHI). See Appendix A for variables definitions.

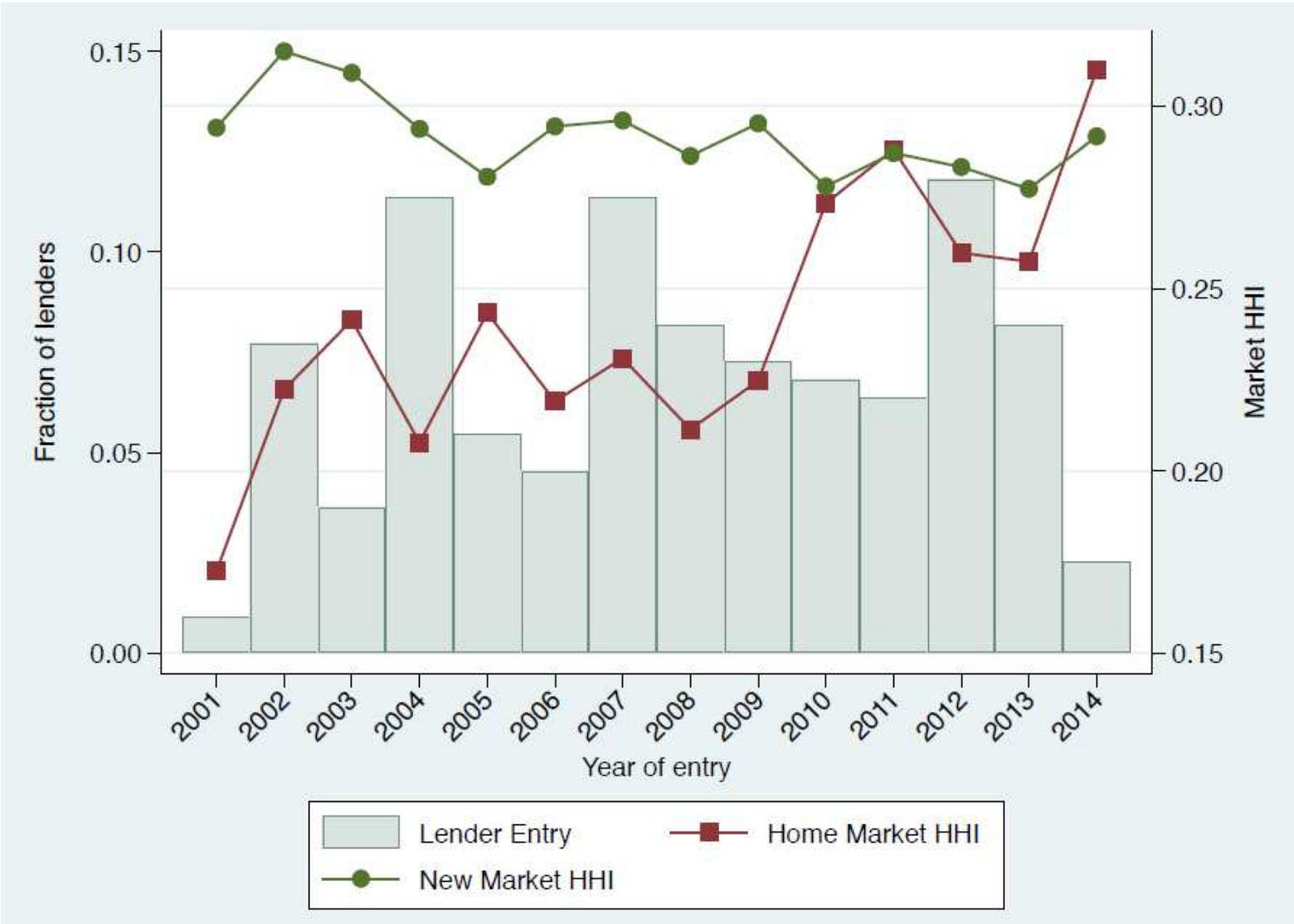




\section{Figure 2: Stock of Bureau Information by Collateral Type}

This figure plots the growth in bureau information coverage for the five most common collateral types in our sample (copiers and fax machines, trucks, construction and mining equipment, agricultural equipment, and computers). Collateral types are summarized in Table A1. Each series measures the growth in number of open contracts in the bureau that year as a percentage of the maximum all time open contracts in the bureau for the collateral type.

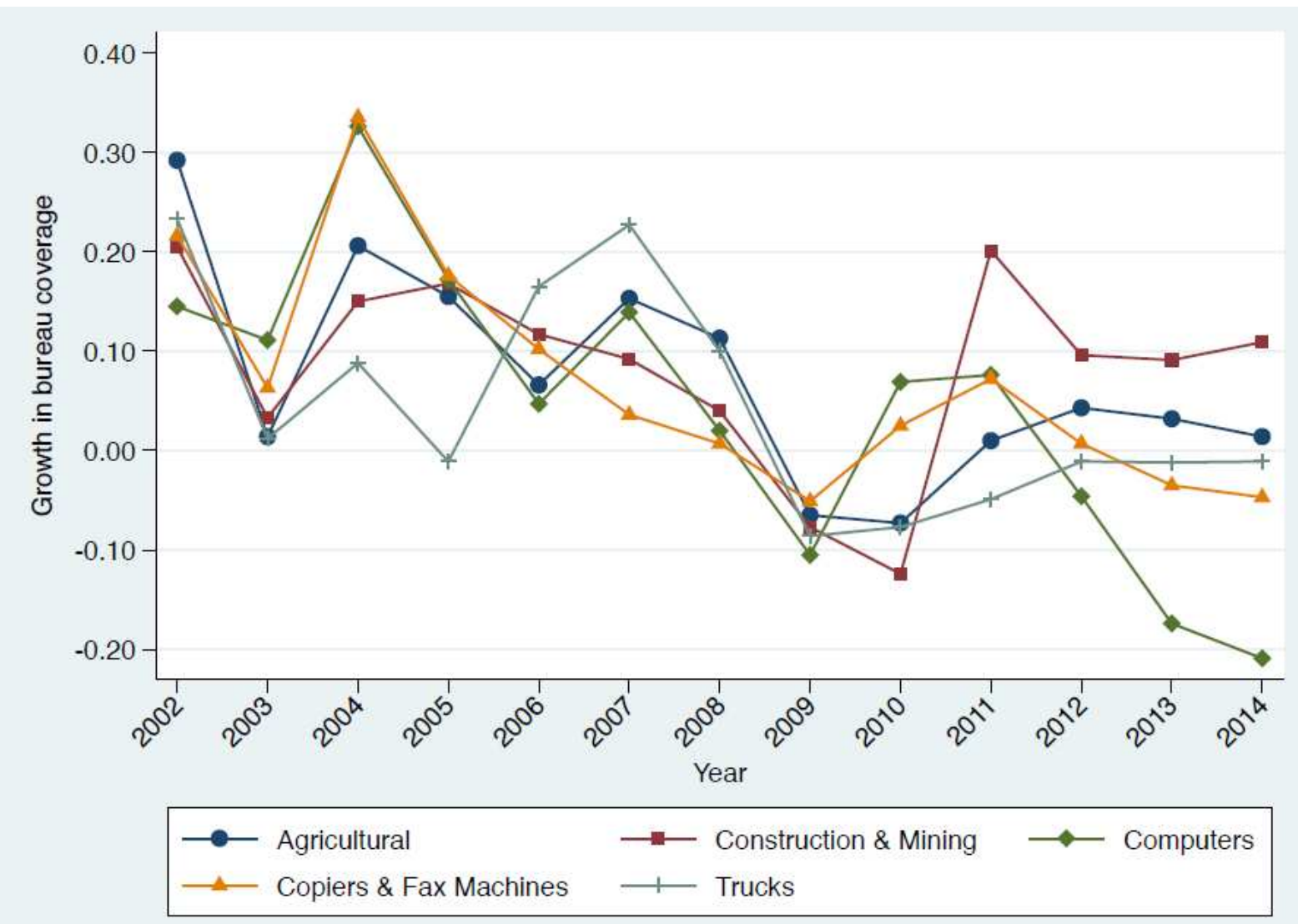




\section{Table 1: Summary Statistics}

This table describes the exposures for lenders in our sample. The unit of observation is a lender, and all variables except Home Market HHI and New Market HHI are measured at the quarter before bureau entry. Home Market HHI and New Market HHI are measured at PayNet's launch. See Appendix A for variables definitions.

\begin{tabular}{lrrrrrr}
\hline \hline & & & & & & \\
& Mean & Std Dev & $25 \%$ & $50 \%$ & $75 \%$ & $N$ \\
\cline { 2 - 7 } Lender Features at Entry & & & & & & \\
\hline Average Contract Size $(\$)$ & 190,692 & 273,269 & 41,445 & 76,308 & 223,081 & 207 \\
Credit (\$ thousands) & 55,015 & 153,625 & 603 & 3,356 & 26,400 & 207 \\
\# Contracts & 481.9 & $1,287.9$ & 8.0 & 32.0 & 169.0 & 207 \\
\# Collateral Types & 5.2 & 5.1 & 1.0 & 3.0 & 8.0 & 207 \\
\# Markets & 18.7 & 26.1 & 3.0 & 8.0 & 25.0 & 207 \\
Lease Share & 0.75 & 0.40 & 0.48 & 1.00 & 1.00 & 207 \\
Home Market HHI & 0.24 & 0.11 & 0.17 & 0.22 & 0.28 & 207 \\
New Market HHI & 0.30 & 0.05 & 0.27 & 0.28 & 0.29 & 207 \\
Home Market Delinquency & 0.17 & 0.10 & 0.10 & 0.16 & 0.22 & 207 \\
New Market Delinquency & 0.16 & 0.06 & 0.11 & 0.15 & 0.18 & 207 \\
Home Market Growth & 0.06 & 0.05 & 0.01 & 0.05 & 0.08 & 207 \\
New Market Growth & 0.02 & 0.07 & -0.01 & 0.01 & 0.04 & 207 \\
& & & & & & \\
\hline \hline
\end{tabular}




\section{Table 2: Time to Bureau Entry and Market, Lender, and Bureau Characteristics}

This table uses OLS to estimate the time to bureau entry as a function of market, lender, and bureau characteristics. The dependent variable is the number of years remaining before the lender enters the bureau (Time to Entry). The sample begins in 1999 and ends when the lender enters the bureau (no post-entry observations are included). The unit of observation is a lenderyear. Reported below the coefficients are t-statistics calculated with standard errors clustered at the lender level. *,**,*** indicate significance at the two-tailed 10\%, 5\%, and $1 \%$ levels, respectively. See Appendix A for variables definitions.

\begin{tabular}{|c|c|c|c|c|c|}
\hline & $\begin{array}{c}\text { (1) } \\
\text { Time to } \\
\text { Entry }\end{array}$ & $\begin{array}{c}(2) \\
\text { Time to } \\
\text { Entry }\end{array}$ & $\begin{array}{c}(3) \\
\text { Time to } \\
\text { Entry }\end{array}$ & $\begin{array}{c}\text { (4) } \\
\text { Time to } \\
\text { Entry }\end{array}$ & $\begin{array}{c}(5) \\
\text { Time to } \\
\text { Entry }\end{array}$ \\
\hline Home Market HHI & $\begin{array}{l}1.891 * \\
{[1.94]}\end{array}$ & $\begin{array}{c}1.768^{*} \\
{[1.86]}\end{array}$ & $\begin{array}{l}1.676^{*} \\
{[1.75]}\end{array}$ & $\begin{array}{l}1.613^{*} \\
{[1.90]}\end{array}$ & $\begin{array}{l}1.475^{*} \\
{[1.84]}\end{array}$ \\
\hline New Market HHI & $\begin{array}{c}-53.601 * * * \\
{[-4.83]}\end{array}$ & $\begin{array}{c}-44.877 * * * \\
{[-6.08]}\end{array}$ & $\begin{array}{c}-55.248 * * * \\
{[-6.60]}\end{array}$ & $\begin{array}{c}-36.108 * * * \\
{[-5.39]}\end{array}$ & $\begin{array}{c}-36.693 * * * \\
{[-5.82]}\end{array}$ \\
\hline Home Market Delinquency & & $\begin{array}{r}-0.753 \\
{[-0.93]}\end{array}$ & $\begin{array}{l}-0.802 \\
{[-0.99]}\end{array}$ & $\begin{array}{c}-1.398 * * \\
{[-2.38]}\end{array}$ & $\begin{array}{c}-1.567 * * \\
{[-2.44]}\end{array}$ \\
\hline New Market Delinquency & & $\begin{array}{c}-47.922 * * * \\
{[-12.60]}\end{array}$ & $\begin{array}{c}-55.034 * * * \\
{[-13.40]}\end{array}$ & $\begin{array}{c}-49.301 * * * \\
{[-12.87]}\end{array}$ & $\begin{array}{c}-50.446^{* * *} \\
{[-13.26]}\end{array}$ \\
\hline Home Market Growth & & & $\begin{array}{c}0.054 * * \\
{[2.30]}\end{array}$ & $\begin{array}{c}0.046^{* *} \\
{[2.09]}\end{array}$ & $\begin{array}{c}0.047 * * \\
{[2.17]}\end{array}$ \\
\hline New Market Growth & & & $\begin{array}{c}11.501 * * * \\
{[4.08]}\end{array}$ & $\begin{array}{c}10.125^{* * * *} \\
{[4.00]}\end{array}$ & $\begin{array}{c}9.778 * * * \\
{[4.00]}\end{array}$ \\
\hline Log Collateral Types & & & & $\begin{array}{c}-0.687 * * \\
{[-2.32]}\end{array}$ & $\begin{array}{c}-0.466^{*} \\
{[-1.77]}\end{array}$ \\
\hline Log Credit & & & & $\begin{array}{c}-0.412 * * * \\
{[-3.33]}\end{array}$ & $\begin{array}{c}-0.307 * * * \\
{[-2.62]}\end{array}$ \\
\hline Lease Share & & & & $\begin{array}{c}-2.065^{* * *} \\
{[-4.96]}\end{array}$ & $\begin{array}{c}-1.737 * * * \\
{[-4.41]}\end{array}$ \\
\hline Log Regions & & & & $\begin{array}{c}0.233 \\
{[0.71]}\end{array}$ & $\begin{array}{c}0.197 \\
{[0.66]}\end{array}$ \\
\hline Log Member Count & & & & & $\begin{array}{c}-0.785^{* * *} \\
{[-10.86]} \\
\end{array}$ \\
\hline Adj R-Sq. & 0.470 & 0.510 & 0.518 & 0.578 & 0.625 \\
\hline $\mathrm{N}$ & 2,114 & 2,114 & 2,114 & 2,114 & 2,114 \\
\hline Year FEs & Yes & Yes & Yes & Yes & Yes \\
\hline
\end{tabular}




\section{Table 3: Information Sharing and Lender Exposures}

This table models lender exposures as a function of bureau membership using specification (1). The dependent variable in column 1 is the log dollar amount of credit (Log Credit). The dependent variable in column 2 is the log number of markets (Log Markets), where markets are defined as unique collateral type-region pairs. Member is an indicator variable equal to one for quarters after the lender has joined the bureau. The sample spans the two years surrounding the lender's entry to the bureau (i.e., four quarters before and four quarters after the entry). The unit of observation is a lender-quarter. Reported below the coefficients are t-statistics calculated with standard errors clustered at the lender level. *,**,*** indicate significance at the two-tailed $10 \%, 5 \%$, and $1 \%$ levels, respectively.

\begin{tabular}{lcc}
\hline \hline & $(1)$ & $(2)$ \\
& Log & Log \\
& Credit & Markets \\
\hline Member & $0.221^{* * *}$ & $0.085^{* * *}$ \\
& {$[5.32]$} & {$[4.51]$} \\
\hline Adj R-Sq. & 0.966 & 0.967 \\
$\mathrm{~N}$ & 1,605 & 1,605 \\
\hline Lender FEs & Yes & Yes \\
Year FEs & Yes & Yes \\
& & \\
\hline \hline
\end{tabular}




\section{Table 4: Exposure Responses to Information Coverage}

This table models how lender exposures respond to changes in bureau information coverage using specification (2). The dependent variable is the log dollar amount of credit (Log Credit) for a given collateral type-region in the lender's portfolio that quarter. Member is an indicator variable equal to one for quarters after the lender has joined the bureau. Coverage is the log number of open contracts appearing in the bureau that quarter for a given collateral type-region. The sample is restricted to collateral types that the lender was exposed to before joining. The unit of observation is at the lender-collateral type-region-quarter level. Reported below the coefficients are t-statistics calculated with standard errors clustered at the lender level. *, **, $* * *$ indicate significance at the two-tailed $10 \%, 5 \%$, and $1 \%$ levels, respectively.

\begin{tabular}{lcc}
\hline \hline & $(1)$ & $(2)$ \\
& Log & Log \\
& Credit & Credit \\
\hline Coverage & 0.009 & \\
& {$[0.40]$} & \\
Member x Coverage & $0.105^{* * *}$ & $0.115^{* * *}$ \\
& {$[3.96]$} & {$[4.62]$} \\
\hline Adj R-Sq. & 0.697 & 0.695 \\
$\mathrm{~N}$ & 170,847 & 170,847 \\
\hline Lender x Collateral Type FEs & Yes & Yes \\
Lender x Quarter FEs & Yes & Yes \\
Region x Collateral Type FEs & Yes & No \\
Region x Collateral Type x Quarter FEs & & Yes \\
& & \\
\hline \hline
\end{tabular}




\section{Table 5: Exposure Responses to Information Coverage by Market Type}

This table uses equation (2) to examine how our Table 4, column 2, results depend on the nature of the collateral type-region market being studied. The dependent variable is the log dollar amount of credit for a given collateral type-region in the lender's portfolio (Log Credit). Member is an indicator variable equal to one for quarters after the lender has joined the bureau. Coverage is the log number of open contracts appearing in the bureau that quarter for a given collateral type-region. The sample is restricted to collateral types that the lender was exposed to before joining. Columns 1-4 split our sample according to whether the market is a home or new market for the lender and whether the market has above or below median HHI. The unit of observation is at the lender-collateral type-region-quarter level. Reported below the coefficients are t-statistics calculated with standard errors clustered at the lender level. *, **, *** indicate significance at the two-tailed $10 \%, 5 \%$, and $1 \%$ levels, respectively.

\begin{tabular}{lcccc}
\hline \hline & $(1)$ & $(2)$ & $(3)$ & $(4)$ \\
& Log & Log & Log & Log \\
& Credit & Credit & Credit & Credit \\
\hline & Home, & New, & Home, & New, \\
& Low HHI & Low HHI & High HHI & High HHI \\
\cline { 2 - 3 } Member x Coverage & 0.033 & $0.096^{* *}$ & 0.076 & $0.139^{* *}$ \\
& {$[0.43]$} & {$[2.30]$} & {$[1.29]$} & {$[2.51]$} \\
\hline Adj R-Sq. & 0.785 & 0.656 & 0.672 & 0.631 \\
N & 37,061 & 51,098 & 32,577 & 50,111 \\
\hline Lender x Collateral Type FEs & Yes & Yes & Yes & Yes \\
Lender x Quarter FEs & Yes & Yes & Yes & Yes \\
Region x Collateral Type x Quarter FEs & Yes & Yes & Yes & Yes \\
& & & & \\
\hline \hline
\end{tabular}




\section{Table 6: Collateral Type Relatedness}

This table presents the most and least related collateral types, according to our index. * indicates significance in relatedness between two collateral types at the $10 \%$ level.

\begin{tabular}{|c|c|c|c|c|}
\hline Collateral Type & Most Related & $\underline{\text { Second Most Related }}$ & Third Most Related & $\underline{\text { Least Related }}$ \\
\hline Agricultural & Real Estate* & Construction \& Mining* & Trucks & Boats \\
\hline Aircraft & Boats & Trucks & Computers & Energy \\
\hline Automobiles & Manufacturing & Construction \& Mining & Medium/Light Duty Trucks & Boats \\
\hline Boats & Aircraft & Railroad & Trucks & Energy \\
\hline Buses \& Motor Coaches & Medium/Light Duty Trucks & Trucks & Manufacturing & Boats \\
\hline Construction \& Mining & Agricultural* & Trucks & Forklifts & Boats \\
\hline Computers & Telecommunications* & Copiers \& Fax Machines* & Office* & Boats \\
\hline Copiers \& Fax Machines & Telecommunications* & Copiers \& Fax Machines* & Office* & Boats \\
\hline Energy & Agricultural & Telecommunications & Office & Boats \\
\hline Forklifts & Construction \& Mining & Agricultural & Manufacturing & Boats \\
\hline Logging \& Forestry & Agricultural & Construction \& Mining & Waste \& Refuse Handling & Boats \\
\hline Medium/Light Duty Trucks & Agricultural & Construction \& Mining & Trucks & Boats \\
\hline Medical & Telecommunications* & Office* & Retail* & Boats \\
\hline Manufacturing & Retail* & Computers* & Office* & Boats \\
\hline Office & Telecommunications* & Copiers \& Fax Machines* & Computers* & Boats \\
\hline Printing \& Photographic & Manufacturing & Retail & Construction & Boats \\
\hline Railroad & Aircraft & Printing \& Photographic & Construction & Energy \\
\hline Real Estate & Agricultural* & Construction \& Mining & Automobiles & Boats \\
\hline Retail & Computer* & Telecommunications* & Copiers \& Fax Machines* & Boats \\
\hline Telecommunications & Copiers \& Fax Machines* & Computers* & Office* & Boats \\
\hline Trucks & Construction \& Mining & Agricultural & Medium/Light Duty Trucks & Boats \\
\hline Vending & Retail* & Computers* & Copiers \& Fax Machines* & Boats \\
\hline Waste \& Refuse Handling & Forklifts & Construction \& Mining & Logging & Boats \\
\hline
\end{tabular}




\section{Table 7: New Collateral Exposure, Collateral Relatedness, and Bureau Information}

This table uses equation (3) to model lender exposures within a new collateral type as a function of relatedness to existing collateral types in the lender's portfolio, bureau membership, and bureau information coverage. The dependent variable is the log dollar amount of credit for a given collateral type in the lender's portfolio (Log Credit). Relatedness is measured as the maximum of the pairwise relatedness scores between the lender's existing collateral types and the given collateral type. Member is an indicator variable equal to one for the period after the lender has joined the bureau. Coverage is the log number of open contracts appearing in the bureau that quarter for a given collateral type. Column 3 includes all main and two-way effects not subsumed by our fixed effects but does not report them for brevity. The sample is restricted to new collateral-collateral types that the lender was not exposed to before entering the bureau. The unit of observation is at the lender-collateral type-quarter level. Reported below the coefficients are t-statistics calculated with standard errors clustered at the lender level. *, $* *, * * *$ indicate significance at the two-tailed 10\%, 5\%, and 1\% levels, respectively. See Appendix A for variable definitions.

\begin{tabular}{lccc}
\hline \hline & $(1)$ & $(2)$ & $(3)$ \\
& Log & Log & Log \\
& Credit & Credit & Credit \\
\hline Relatedness & $0.912^{* * * *}$ & & \\
& {$[5.59]$} & & \\
Member x Relatedness & $0.767^{* * *}$ & $0.653^{* * *}$ & -0.186 \\
& {$[6.27]$} & {$[7.24]$} & {$[-0.72]$} \\
Member x Relatedness x Coverage & & & $0.678^{* *}$ \\
& & & {$[2.24]$} \\
\hline Adj R-Sq. & 0.363 & 0.726 & 0.727 \\
$\mathrm{~N}$ & 186,789 & 186,789 & 186,789 \\
\hline Collateral Type FEs & Yes & No & No \\
Lender x Collateral Type FEs & No & Yes & Yes \\
Lender x Quarter FEs & Yes & Yes & Yes \\
& & & \\
\hline \hline
\end{tabular}




\section{Table 8: Information Sharing and Exposures by Lender Size and Focus}

This table uses equation (1) to model lender exposures as a function of bureau membership, lender size, and lender focus. The dependent variable in Panel A and B is the log dollar amount of credit in the lender's portfolio (Log Credit) and the share of the lender's clients in the smallest quartile of total credit within the collateral type-quarter (Small Client Share), respectively. Member is an indicator variable equal to one for quarters after the lender has joined the bureau. Large Lender is an indicator variable equal to one for lenders with above median total credit. \# Collateral Types is the log number of collateral types in the lender's portfolio. Column 5 includes Lender Size-Year FEs and Lender Focus-Year FEs. Both Lender Size and Lender Focus are categories defined at the median. The sample spans the two years surrounding the lender's entry to the bureau. The unit of observation is at the lender-quarter level. Reported below the coefficients are t-statistics calculated with standard errors clustered at the lender level. *,**,*** indicate significance at the two-tailed 10\%, 5\%, and $1 \%$ levels, respectively. See Appendix A for variables definitions.

Panel A: Log Credit

\begin{tabular}{lccccc}
\hline \hline & $(1)$ & $(2)$ & $(3)$ & $(4)$ & $(5)$ \\
& Log & Log & Log & Log & Log \\
& Credit & Credit & Credit & Credit & Credit \\
\hline Member & $0.221^{* * *}$ & $0.333^{* * *}$ & $0.417^{* * *}$ & $0.449^{* * *}$ & $0.400^{* * *}$ \\
& {$[5.32]$} & {$[4.49]$} & {$[5.28]$} & {$[5.17]$} & {$[4.65]$} \\
Member x Large Lender & & $-0.225^{* *}$ & & $-0.173^{*}$ & $-0.194 * *$ \\
& & {$[-2.44]$} & & {$[-1.83]$} & {$[-2.18]$} \\
Member x \# Collateral Types & & & $-0.200^{* * * *}$ & $-0.144 * * *$ & $-0.084 * *$ \\
& & & {$[-3.82]$} & {$[-2.78]$} & {$[-2.34]$} \\
\hline Adj R-Sq. & 0.966 & 0.966 & 0.966 & 0.966 & 0.966 \\
$\mathrm{~N}$ & 1,605 & 1,605 & 1,605 & 1,605 & 1,605 \\
\hline Lender FEs & Yes & Yes & Yes & Yes & Yes \\
Year FEs & Yes & Yes & Yes & Yes & No \\
Lender Size x Year FEs & No & No & No & No & Yes \\
Lender Focus x Year FEs & No & No & No & No & Yes \\
& & & & & \\
\hline \hline
\end{tabular}


Panel B: Exposure to Small Firms

\begin{tabular}{lccccc}
\hline \hline & $(1)$ & $(2)$ & $(3)$ & $(4)$ & $(5)$ \\
& $\begin{array}{c}\text { Small } \\
\text { Client Share }\end{array}$ & $\begin{array}{c}\text { Small } \\
\text { Client Share }\end{array}$ & $\begin{array}{c}\text { Small } \\
\text { Client Share }\end{array}$ & $\begin{array}{c}\text { Small } \\
\text { Client Share }\end{array}$ & $\begin{array}{c}\text { Small } \\
\text { Member }\end{array}$ \\
& -0.009 & -0.021 & -0.013 & -0.018 & -0.021 \\
& {$[-1.06]$} & {$[-1.52]$} & {$[-0.92]$} & {$[-1.13]$} & {$[-1.21]$} \\
Member x Large Lender & & $0.025^{*}$ & & $0.027^{*}$ & $0.033^{*}$ \\
& & {$[1.76]$} & & {$[1.90]$} & {$[1.96]$} \\
Member x \# Collateral Types & & & 0.004 & -0.004 & -0.005 \\
& & & {$[0.60]$} & {$[-0.94]$} & {$[-1.30]$} \\
\hline Adj R-Sq. & 0.848 & 0.848 & 0.848 & 0.848 & 0.848 \\
$\mathrm{~N}$ & 1,605 & 1,605 & 1,605 & 1,605 & 1,605 \\
\hline Lender FEs & Yes & Yes & Yes & Yes & Yes \\
Year FEs & Yes & Yes & Yes & Yes & No \\
Lender Size x Year FEs & No & No & No & No & Yes \\
Lender Focus x Year FEs & No & No & No & No & Yes \\
& & & & & \\
\hline \hline
\end{tabular}




\section{Table 9: Information Sharing and Borrower Credit Access}

This table models a borrower's access to credit as a function of whether its credit file is available in the bureau. The dependent variable in columns 1 and 2 is the borrower's log number of lending relationships (Log \# of Lending Relationships) and log total credit ( $\operatorname{og}$ Borrower Credit), respectively. The dependent variable in column 3 is an indicator variable for whether the borrower starts a new relationship without having an old contract maturing in that quarter or a surrounding quarter (Starts New Relationship Off Cycle). Post File is an indicator equal to one for the period after the borrower first appears in the bureau. The unit of observation is at the borrower-quarter level. Reported below the coefficients are t-statistics calculated with standard errors clustered at the borrower level. *,**,*** indicate significance at the two-tailed $10 \%, 5 \%$, and $1 \%$ levels, respectively. See Appendix A for variables definitions.

\begin{tabular}{lccc}
\hline \hline & $\begin{array}{c}(1) \\
\text { Log \# } \\
\text { of Lending } \\
\text { Relationships }\end{array}$ & $\begin{array}{c}\text { Log } \\
\text { Borrower } \\
\text { Credit }\end{array}$ & $\begin{array}{c}\text { Starts New } \\
\text { Relationship } \\
\text { Off Cycle }\end{array}$ \\
\hline Post File & $0.060^{* * *}$ & $0.118^{* * *}$ & $0.007^{* * *}$ \\
& {$[17.94]$} & {$[6.75]$} & {$[4.75]$} \\
\hline Adj R-Sq. & 0.675 & 0.747 & 0.009 \\
$\mathrm{~N}$ & 674,985 & 674,985 & 674,985 \\
\hline Borrower FEs & Yes & Yes & Yes \\
Industry x Quarter FEs & Yes & Yes & Yes \\
& & & \\
\hline \hline
\end{tabular}


Online Appendix to:

\section{Economics of Voluntary Information Sharing}

August 2018

This online appendix tabulates additional analyses not reported in the paper. 


\section{Table A1: Collateral Type Exposures}

This table summarizes the number of lenders with contracts for each collateral type.

\begin{tabular}{lr} 
Collateral Type & \# Lenders \\
\cline { 2 - 2 } Agricultural & 67 \\
Aircraft & 16 \\
Automobiles & 56 \\
Boats & 9 \\
Buses \& Motor Coaches & 40 \\
Construction \& Mining & 110 \\
Computers & 101 \\
Copiers \& Fax Machines & 53 \\
Energy & 9 \\
Forklifts & 50 \\
Logging \& Forestry & 30 \\
Medium/Light Duty Trucks & 67 \\
Medical & 79 \\
Manufacturing & 97 \\
Office & 73 \\
Printing \& Photographic & 53 \\
Railroad & 16 \\
Real Estate & 20 \\
Retail & 99 \\
Telecommunications & 69 \\
Trucks & 121 \\
Vending & 49 \\
Waste \& Refuse Handling & 37 \\
& \\
\hline
\end{tabular}




\section{Table A2: Time to Bureau Entry-Robustness}

This table presents robustness analyses for our Table 2 tests. The dependent variable is the number of years remaining before the lender enters the bureau (Time to Entry). The sample begins in 1999 and ends when the lender enters the bureau. Column 1 restricts the sample to lenders joining in 2004 or later, reducing the number of observations to 1,967. Column 2 reports the average coefficients and t-statistics from 1,000 trials of a placebo analysis, where we counterfactually assign lenders to random entry years. Column 3 defines the lender's home and new markets using their exposures in the second quarter of 2001. The unit of observation is a lender-year. Reported below the coefficients are t-statistics calculated with standard errors clustered at the lender level. *,**,*** indicate significance at the two-tailed $10 \%, 5 \%$, and $1 \%$ levels, respectively. See Appendix A for variables definitions.

\begin{tabular}{|c|c|c|c|}
\hline & $\begin{array}{c}\text { (1) } \\
\text { Time to } \\
\text { Entry }\end{array}$ & $\begin{array}{c}(2) \\
\text { Time to } \\
\text { Entry }\end{array}$ & $\begin{array}{c}(3) \\
\text { Time to } \\
\text { Entry }\end{array}$ \\
\hline Home Market HHI & $\begin{array}{l}1.270^{*} \\
{[1.66]}\end{array}$ & $\begin{array}{c}-0.124 \\
{[-0.10]}\end{array}$ & $\begin{array}{c}2.378 * * \\
{[1.98]}\end{array}$ \\
\hline New Market HHI & $\begin{array}{c}-24.510 * * \\
{[-2.06]}\end{array}$ & $\begin{array}{c}-1.407 \\
{[-0.13]}\end{array}$ & $\begin{array}{c}-16.212^{* *} \\
{[-2.06]}\end{array}$ \\
\hline Home Market Growth & $\begin{array}{c}-0.006 \\
{[-0.17]}\end{array}$ & $\begin{array}{l}0.000 \\
{[0.02]}\end{array}$ & $\begin{array}{r}0.007 \\
{[0.20]}\end{array}$ \\
\hline New Market Growth & $\begin{array}{l}-2.376 \\
{[-0.39]}\end{array}$ & $\begin{array}{l}0.021 \\
{[0.14]}\end{array}$ & $\begin{array}{c}4.473 * * * \\
{[3.83]}\end{array}$ \\
\hline Home Market Delinquency & $\begin{array}{c}-1.756^{* * *} \\
{[-2.84]}\end{array}$ & $\begin{array}{c}-0.101 \\
{[-0.04]}\end{array}$ & $\begin{array}{c}-3.133 * * * \\
{[-3.91]}\end{array}$ \\
\hline New Market Delinquency & $\begin{array}{c}-90.529 * * * \\
{[-19.01]}\end{array}$ & $\begin{array}{c}0.342 \\
{[0.07]}\end{array}$ & $\begin{array}{c}-48.886 * * * \\
{[-12.09]}\end{array}$ \\
\hline Log Collateral Types & $\begin{array}{c}-0.244 \\
{[-0.98]}\end{array}$ & $\begin{array}{l}0.023 \\
{[0.05]}\end{array}$ & $\begin{array}{c}-0.568 * * \\
{[-2.11]}\end{array}$ \\
\hline Log Credit & $\begin{array}{c}-0.197 * \\
{[-1.84]}\end{array}$ & $\begin{array}{l}0.009 \\
{[0.07]}\end{array}$ & $\begin{array}{c}-0.374 * * * \\
{[-2.92]}\end{array}$ \\
\hline Lease Share & $\begin{array}{c}-1.663 * * * \\
{[-4.33]}\end{array}$ & $\begin{array}{l}0.026 \\
{[0.04]}\end{array}$ & $\begin{array}{c}-1.727 * * * \\
{[-4.28]}\end{array}$ \\
\hline Log Regions & $\begin{array}{c}0.323 \\
{[1.14]}\end{array}$ & $\begin{array}{l}0.006 \\
{[0.01]}\end{array}$ & $\begin{array}{c}0.365 \\
{[1.25]}\end{array}$ \\
\hline Log Member Count & $\begin{array}{c}-0.772 * * * \\
{[-10.74]}\end{array}$ & $\begin{array}{r}0.008 \\
{[0.03]}\end{array}$ & $\begin{array}{c}-0.739 * * * \\
{[-10.47]}\end{array}$ \\
\hline $\begin{array}{l}\text { Adj R-Sq. } \\
\mathrm{N}\end{array}$ & $\begin{array}{l}0.681 \\
1,967\end{array}$ & & $\begin{array}{l}0.618 \\
2,114\end{array}$ \\
\hline Year FEs & Yes & Yes & Yes \\
\hline
\end{tabular}




\section{Table A3: Contract and State Exposure Responses to Information Coverage}

This table presents robustness analyses of our Table 4, column 2 results. The dependent variable in column 1 and 2 is the log number of contracts (Log Contracts) and log number of state exposures (Log States), respectively, for a given collateral type-region in the lender's portfolio. Member is an indicator equal to one for quarters after the lender has joined the bureau. Coverage is the log number of open contracts appearing in the bureau that quarter for a given collateral type-region. The sample is restricted to collateral types that the lender was exposed to before joining. The unit of observation is lender-collateral type-region-quarter. Reported below the coefficients are t-statistics calculated with standard errors clustered at the lender level. *,**,*** indicate significance at the two-tailed $10 \%, 5 \%$, and $1 \%$ levels, respectively. See Appendix A for variables definitions.

\begin{tabular}{lcc}
\hline \hline & $(1)$ & $(2)$ \\
& Log & Log \\
& Contracts & States \\
\hline Member x Coverage & $0.099 * * *$ & $0.015^{* * *}$ \\
& {$[5.84]$} & {$[3.11]$} \\
\hline Adj R-Sq. & 0.745 & 0.630 \\
$\mathrm{~N}$ & 170,847 & 170,847 \\
\hline Lender x Collateral Type FEs & Yes & Yes \\
Lender x Quarter FEs & Yes & Yes \\
Region x Collateral Type x Quarter FEs & Yes & Yes \\
& & \\
\hline \hline
\end{tabular}




\section{Table A4: Exposure Responses to Information Coverage-Robustness}

This table presents robustness analyses of our Table 4, column 2, results. The dependent variable is the log dollar amount of credit for a given collateral type-region in the lender's portfolio (Log Credit). Member is an indicator variable equal to one for quarters after the lender has joined the bureau. Coverage Placebo is the log number of open contracts excluding collateral type $j$ appearing in the bureau that region-quarter. Stale Coverage is the log number of open contracts appearing in the bureau four quarters ago for a given collateral type-region. Coverage is the log number of open contracts appearing in the bureau that quarter for a given collateral type-region. The sample is restricted to collateral types that the lender was exposed to before joining. Column 3 excludes the five largest lenders; columns 4 and 5 split the sample according to when the lender joined the bureau. The unit of observation is at the lendercollateral type-quarter level. Reported below the coefficients are t-statistics calculated with standard errors clustered at the lender level. *,**,*** indicate significance at the two-tailed $10 \%, 5 \%$, and $1 \%$ levels, respectively. See Appendix A for variables definitions.

\begin{tabular}{|c|c|c|c|c|c|}
\hline & $\begin{array}{c}(1) \\
\text { Log } \\
\text { Credit }\end{array}$ & $\begin{array}{c}(2) \\
\text { Log } \\
\text { Credit }\end{array}$ & $\begin{array}{c}(3) \\
\text { Log } \\
\text { Credit }\end{array}$ & $\begin{array}{c}(4) \\
\text { Log } \\
\text { Credit }\end{array}$ & $\begin{array}{c}(5) \\
\text { Log } \\
\text { Credit } \\
\end{array}$ \\
\hline Member x Coverage Placebo & $\begin{array}{c}\text { Full } \\
\text { Sample } \\
-0.204 \\
{[-0.80]}\end{array}$ & $\begin{array}{c}\text { Full } \\
\text { Sample }\end{array}$ & $\begin{array}{l}\text { Drop } 5 \\
\underline{\text { Largest }}\end{array}$ & 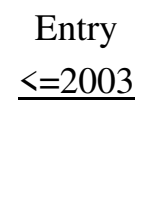 & $\begin{array}{c}\text { Entry } \\
\geq 2003 \\
\end{array}$ \\
\hline Member x Stale Coverage & & $\begin{array}{c}0.084 * * * \\
{[3.53]}\end{array}$ & & & \\
\hline Member x Coverage & & & $\begin{array}{c}0.115 * * * \\
{[3.75]} \\
\end{array}$ & $\begin{array}{c}0.104 * * \\
{[2.20]}\end{array}$ & $\begin{array}{c}0.086^{* * *} \\
{[2.55]} \\
\end{array}$ \\
\hline Adj R-Sq. & 0.694 & 0.695 & 0.683 & 0.696 & 0.664 \\
\hline $\mathrm{N}$ & 170,847 & 170,847 & 137,042 & 83,438 & 87,409 \\
\hline Lender x Collateral Type FEs & Yes & Yes & Yes & Yes & Yes \\
\hline Lender x Quarter FEs & Yes & Yes & Yes & Yes & Yes \\
\hline Region x Collateral Type x Quarter FEs & Yes & Yes & Yes & Yes & Yes \\
\hline
\end{tabular}

